\title{
Quantitative transcription dynamic analysis reveals candidate genes and key regulators for ethanol tolerance in Saccharomyces cerevisiae
}

\author{
Menggen Ma1,2 and Lewis Z Liu*1
}

\begin{abstract}
Background: Derived from our lignocellulosic conversion inhibitor-tolerant yeast, we generated an ethanol-tolerant strain Saccharomyces cerevisiae NRRL Y-50316 by enforced evolutionary adaptation. Using a newly developed robust mRNA reference and a master equation unifying gene expression data analyses, we investigated comparative quantitative transcription dynamics of 175 genes selected from previous studies for an ethanol-tolerant yeast and its closely related parental strain.

Results: A highly fitted master equation was established and applied for quantitative gene expression analyses using pathway-based qRT-PCR array assays. The ethanol-tolerant Y-50316 displayed significantly enriched background of mRNA abundance for at least 35 genes without ethanol challenge compared with its parental strain Y-50049. Under the ethanol challenge, the tolerant Y-50316 responded in consistent expressions over time for numerous genes belonging to groups of heat shock proteins, trehalose metabolism, glycolysis, pentose phosphate pathway, fatty acid metabolism, amino acid biosynthesis, pleiotropic drug resistance gene family and transcription factors. The parental strain showed repressed expressions for many genes and was unable to withstand the ethanol stress and establish a viable culture and fermentation. The distinct expression dynamics between the two strains and their close association with cell growth, viability and ethanol fermentation profiles distinguished the tolerance-response from the stressresponse in yeast under the ethanol challenge. At least 82 genes were identified as candidate and key genes for ethanol-tolerance and subsequent fermentation under the stress. Among which, 36 genes were newly recognized by the present study. Most of the ethanol-tolerance candidate genes were found to share protein binding motifs of transcription factors Msn4p/Msn2p, Yap1p, Hsf1p and Pdr1p/Pdr3p.

Conclusion: Enriched background of transcription abundance and enhanced expressions of ethanol-tolerance genes associated with heat shock proteins, trehalose-glycolysis-pentose phosphate pathways and PDR gene family are accountable for the tolerant yeast to withstand the ethanol stress, maintain active metabolisms, and complete ethanol fermentation under the ethanol stress. Transcription factor Msn4p appeared to be a key regulator of gene interactions for ethanol-tolerance in the tolerant yeast Y-50316.
\end{abstract}

\section{Background}

Cellulosic ethanol production from renewable biomass including lignocellulosic materials and agricultural residues is a promising alternative to fossil oil as transportation energy [1-6]. Increased ethanol titer or concentration of microbial fermentation has been considered as a strategy to reduce energy cost in downstream

* Correspondence: zlewis.liu@ars.usda.gov

1 Bioenergy Research, National Center for Agricultural Utilization Research USDA-ARS, Peoria, IL USA

Full list of author information is available at the end of the article distillation and waste treatment [7]. Saccharomyces cerevisiae is a traditional ethanol producer, yet it is sensitive to high concentrations of ethanol. Ethanol diffuses freely across biological membranes in yeast cells allowing equalization of ethanol concentrations between intracellular and extracellular pools. As a result, the increased ethanol concentration in a medium inhibits cell growth, damages cell viability, and reduces ethanol yield [8-10]. Using ethanol tolerant strains for high ethanol yield fermentation is desirable for cost-efficient ethanol production. However, mechanisms of ethanol tolerance are not 
well known and ethanol-tolerant yeast is not readily available.

More than 400 genes have been identified involving ethanol tolerance by high throughput assays [11-21]. Most genes are related to heat shock protein genes [11,21-23], trehalose biosynthesis and amino acid pathways $[13,17,24,25]$, fatty acid and ergosterol [15,26-30]. While a significant amount of gene expression data was obtained over the past decade, a lack of solid characterization of expression dynamics exists. For example, studies using snapshot methods were common and often lower concentrations of ethanol were applied at late stages of cell growth (Table 1). When a serial of samples were taken over time, there is usually no additional ethanol challenge applied. As a result, it is very difficult to avoid biased assessment for the complex interactions of ethanol tolerance in yeast.

Yeast tolerance to ethanol is complex involving multiple genes and multiple quantitative trait loci [31]. Development of ethanol-tolerant strains has been hindered by using conventional genetic engineering methods. On the other hand, yeast is adaptable to stress conditions under directed evolutionary engineering [2,32-34]. Adaptation and evolutionary engineering have been successfully applied in obtaining ethanol tolerant strains at varied levels $[26,27,35,36]$. Previously, we developed tolerant etha- nologenic yeast $S$. cerevisiae NRRL Y-50049 that is able to withstand and in situ detoxify numerous fermentation inhibitors that are derived from lignocellulose-to-ethanol conversion such as furfural and 5-hydroxymethylfurfural (HMF) $[33,37,38]$. Building upon the inhibitor-tolerant yeast, we recently developed ethanol-tolerant yeast NRRL Y-50316 using an adaptation evolutionary engineering method under laboratory settings.

The qRT-PCR is an accurate assay platform and considered as an assay of choice for quantitative gene expression analysis. It is commonly used to confirm high throughput expression data obtained by microarray which has higher levels of variations from multiple sources. For absolute quantitative gene expression analysis, due to the necessary wells required for the construction of standard curves, very limited number of wells are available for target gene assays $[37,39]$. Recently, a significant advance has been made to safeguard data accuracy and reproducibility with two new components, a robust mRNA serving as PCR cycle threshold reference and a master equation of standard curves $[37,40,41]$. These developments allow unification of expression data from different experimental conditions for comparative analyses. This method and other similar approaches have been rigorously examined with demonstrated advantages of reliability and reproducibility over housekeeping genes $[37,40-45]$.

Table 1: Recent studies on gene expression response and genes related to ethanol tolerance for Saccharomyces cerevisiae

\begin{tabular}{|c|c|c|c|c|c|c|}
\hline Method & Strain & Growth condition & Cell growth stage & $\begin{array}{c}\text { Ethanol challenge } \\
\text { concentration }(\%, v / v)\end{array}$ & $\begin{array}{l}\text { Sampling time- } \\
\text { points }\end{array}$ & Reference \\
\hline \multirow{2}{*}{$\begin{array}{l}\text { qRT-PCR } \\
\text { Array }\end{array}$} & NRRL Y-50316 & $\mathrm{YM}, 30^{\circ} \mathrm{C}$ & $\mathrm{OD}_{600}=0.15$ & 8 & $0,1,6,24,48 \mathrm{~h}$ & This work \\
\hline & NRRL Y-50049 & & & & & \\
\hline Microarray & S288c & $\mathrm{YPD}, 28^{\circ} \mathrm{C}$ & $\mathrm{OD}_{660}=0.8$ & 7 & $0,0.5 \mathrm{~h}$ & {$[11]$} \\
\hline \multirow[t]{2}{*}{ Microarray } & PMY 1.1 & $\mathrm{YNB}, 30^{\circ} \mathrm{C}$ & $\mathrm{OD}_{620}=1.0$ & 5 & $0,1,3 \mathrm{~h}$ & {$[12]$} \\
\hline & FY834 & & & & & \\
\hline Microarray & S288c IFO2347 & YPD, $30^{\circ} \mathrm{C}$ & $\mathrm{OD}_{660}=1.0$ & 5 & $0,0.25,0.5,1,2,3$ & [13] \\
\hline Microarray & FY834 A1 & $\mathrm{YPD}, 30^{\circ} \mathrm{C}$ & Initial & 10 & log phase & {$[15]$} \\
\hline \multirow[t]{3}{*}{ Microarray } & $\operatorname{Vin} 13$ & Grape juice, $30^{\circ} \mathrm{C}$ & None & 0 & $\begin{array}{l}\text { Varied ethanol } \\
\text { concentrations }\end{array}$ & [16] \\
\hline & K7 & & & & & \\
\hline & K11 & & & & & \\
\hline Microarray & K701 SR4-3 & YPAD, $20^{\circ} \mathrm{C}$ & None & 0 & log phase & {$[17]$} \\
\hline \multirow[t]{2}{*}{ Microarray } & EC1118 & Synthetic must, $24^{\circ} \mathrm{C}$ & None & 0 & $\begin{array}{l}\text { Fermentation } \\
\text { stages } 1 \text { to } 6\end{array}$ & [18] \\
\hline & $\mathrm{K}-9$ & & & & & \\
\hline Microarray & $\mathrm{X} 2180-1 \mathrm{~A}$ & $\mathrm{YPD}, 30^{\circ} \mathrm{C}$ & None & 0 & log phase & [19] \\
\hline SAGE & EC1118 & Synthetic must, $28^{\circ} \mathrm{C}$ & None & 0 & $0,20,48,96 \mathrm{~h}$ & {$[20]$} \\
\hline Microarray & Kyokai no. 701 & Sake mash, $15^{\circ} \mathrm{C}$ & None & 0 & $\begin{array}{l}2,3,4,5,6,8,11,14 \\
17 \text { day }\end{array}$ & {$[21]$} \\
\hline
\end{tabular}


In the present study, we compared cell growth, cell viability, ethanol production and gene expression under the ethanol stress between two very closely related strains, the lignocellulosic inhibitor-tolerant Y-50049 and its ethanol-tolerant derivative Y-50316 retaining the inhibitortolerance characteristics. Using the recently developed pathway-based qRT-PCR array assays, we investigated transcription dynamics of over 170 selected genes based on previous reports and our preliminary screening in response to ethanol challenge using a time-course study. The objective of this study was to identify candidate and key genes responsible for ethanol tolerance to support complete ethanol fermentation. Our results uncovered previously unreported genes accountable for ethanol tolerance and identified legitimate candidate genes of ethanol tolerance based on the ethanol-tolerant Y-50316. Results of this study will aid dissection of ethanol tolerance mechanisms in yeast and metabolic engineering efforts for more tolerant strain development.

\section{Results}

\section{Tolerance and viability}

On a solid medium of $2 \%$ glucose containing $8 \%$ ethanol, ethanol-tolerant strain Y-50316 showed cell growth from reduced cell concentrations at 10 - to 100 -fold dilutions (Figure 1A). In contrast, cells of Y-50049 failed to grow at any reduced cell concentration levels. Strain Y-50316, an ethanol-tolerant derivative from its parental Y-50049, maintained the inhibitor-tolerance and able to in situ detoxify furfural and HMF derived from pretreatment of lignocellulosic biomass. On a medium of $2 \%$ glucose containing furfural and HMF at $10 \mathrm{mM}$ each, both strains

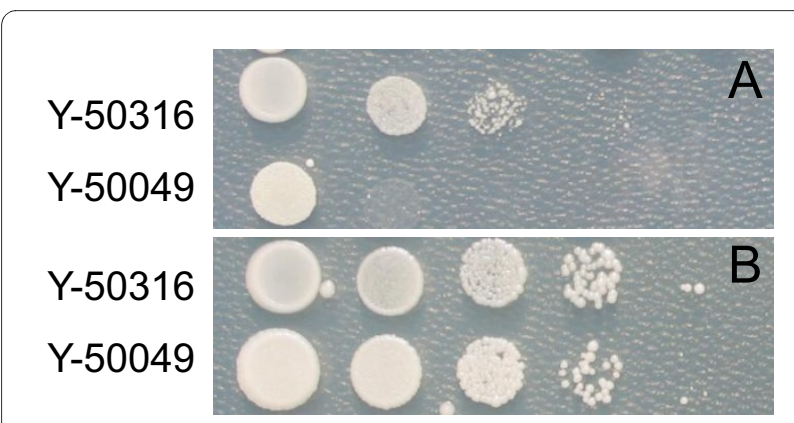

Figure 1 Cell growth response to ethanol and inhibitors. Comparison of cell growth and colony appearance for ethanol-tolerant and inhibitor-tolerant mutant Saccharomyces cerevisiae NRRL Y-50316 and its parental inhibitor-tolerant strain NRRL Y-50049 on YM plate of 2\% glucose containing $8 \%(\mathrm{v} / \mathrm{V})$ ethanol (A) or amended with inhibitors of furfural and 5-hydroxymethylfurfural each at $10 \mathrm{mM}$ (B). The cultures initially applied were estimated with viable cell account of approximately $1.0 \times 10^{7}$ per $\mathrm{ml}$ as measured by colony forming units. A seria of 10 -fold culture dilutions in water were spotted onto a medium plate containing ethanol or inhibitors and cell growth examined 7 days after incubation at $30^{\circ} \mathrm{C}$. showed similar growth patterns against the inhibitors at all cell dilution levels from 10- to 1000-fold (Figure 1B). On a liquid YM of $2 \%$ glucose containing furfural and HMF, both strains showed similar growth pattern and reached stationary phase in $30 \mathrm{~h}$ (data not shown)

On a liquid YM of $10 \%$ glucose containing $8 \%$ ethanol, the ethanol-tolerant Y-50316 displayed a nearly normal growth and reached stationary phase $24 \mathrm{~h}$ after incubation (Figure 2A). For its parental strain Y-50049, cell mass was low and cell growth appeared ceased after $24 \mathrm{~h}$. When cell viability was tested using solid YM of $2 \%$ glucose inoculated with the cell cultures at different time point, the parental strain Y-50049 showed a very poor growth response at $24 \mathrm{~h}$ and no viable cell growth was observed at any later time points (Figure 2B). On the other hand, the ethanol-tolerant strain Y-50316 displayed a normal growth for samples taken at $24 \mathrm{~h}$ till $96 \mathrm{~h}$ after the ethanol challenge. Reduced cell growth and cell lyses were observed for samples taken at 120 to $168 \mathrm{~h}$ after ethanol challenge when the fermentation was completed for several days.

\section{Glucose consumption and ethanol production}

With the addition of ethanol at $8 \%(\mathrm{v} / \mathrm{v}) 6 \mathrm{~h}$ after inoculation, yeast growth of the two strains showed a similar OD reading briefly followed by an obvious separation after 18 $\mathrm{h}$ between the ethanol-tolerant strain Y-50316 and its parental strain Y-50049. Strain Y-50316 exhibited a continued growth through a log phase in $48 \mathrm{~h}$ to reach an

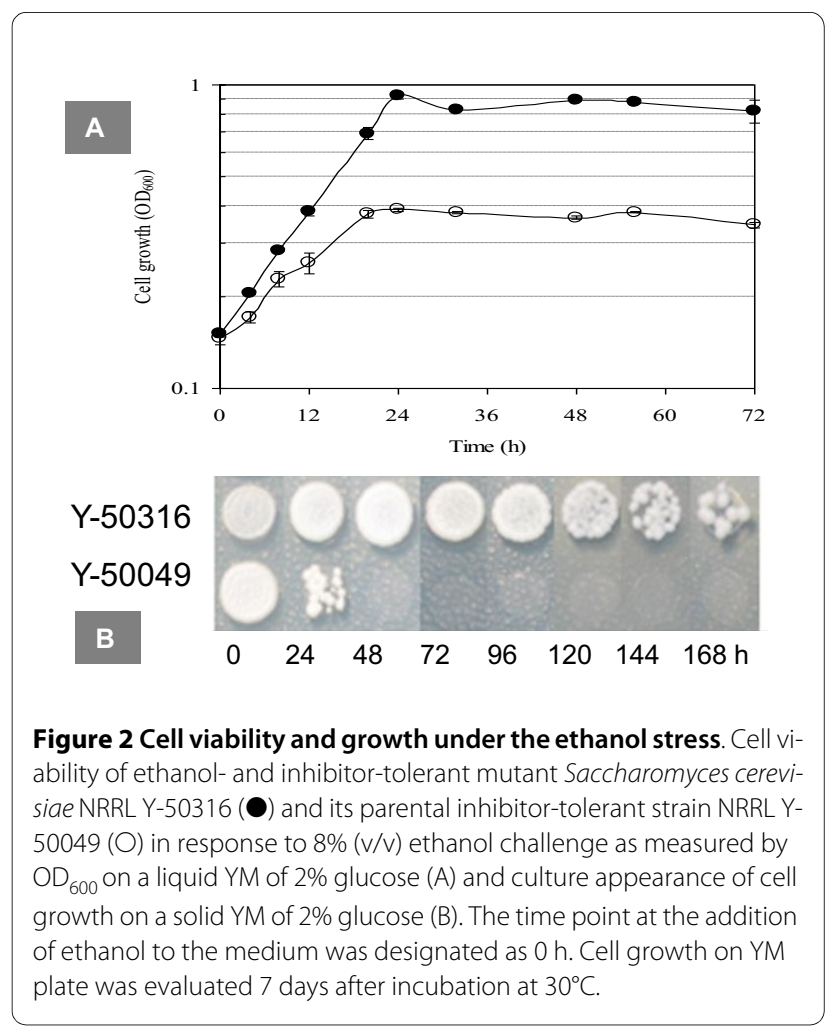


$\mathrm{OD}_{600}$ reading of 1.3 when the ethanol concentration was $75.1 \mathrm{~g} / \mathrm{L}(9.5 \%, \mathrm{v} / \mathrm{v})$ (Figure $3 \mathrm{~A}$ and $3 \mathrm{~B})$. On the other hand, Y-50049 ceased growth since $18 \mathrm{~h}$ and apparently went into cell lysis stages and never recovered. Consequently, no glucose consumption and ethanol conversion were observed for Y-50049 under the ethanol challenge (Figure 3B). In contrast, the ethanol-tolerant strain Y50316 displayed an accelerated glucose consumption and ethanol conversion after $24 \mathrm{~h}$ (Figure 3B). At $120 \mathrm{~h}$, glucose was almost exhausted and the total ethanol concentration reached $96 \mathrm{~g} / \mathrm{L}$. Production of glycerol and acetic acid under the conditions of this study was insignificant (data not shown).

\section{Master equation for qRT-PCR Assays}

Using $C A B$ as a sole reference to set a manual threshold at $26 \mathrm{Ct}$ for data acquisition (see methods) [40], raw data
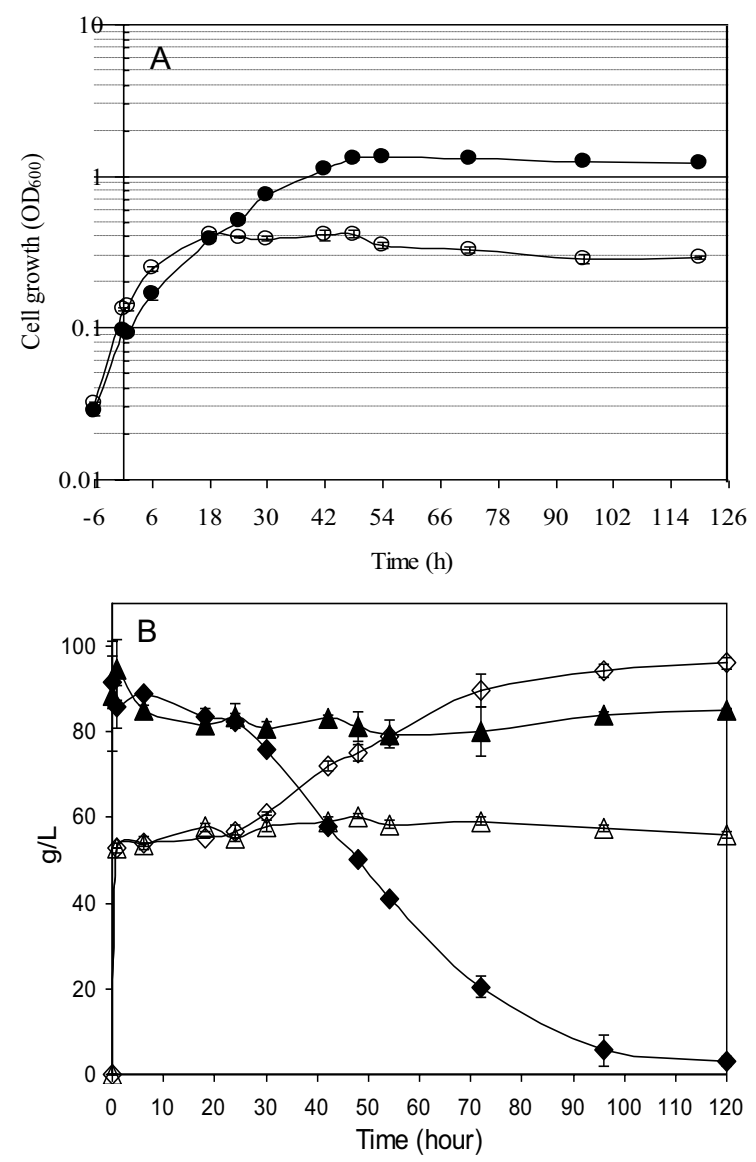

Figure 3 Fermentation profiles under the ethanol stress. Comparison of cell growth and ethanol conversion of Saccharomyces cerevisiae NRRL Y-50316 and NRRL Y-50049 over time in response to 8\% (v/V) ethanol challenge on YM medium with 10\% glucose. (A) Cell growth as measured by $\mathrm{OD}_{600}$ for $\mathrm{Y} 50316(\mathbf{0})$ and $\mathrm{Y}-50049(\mathrm{O})$. (B) Mean values of glucose consumption (?) and ethanol concentration $(\diamond)$ for $Y-50316$ versus glucose $(\boldsymbol{\Delta})$ and ethanol $(\Delta)$ for $\mathrm{Y}-50049$. were normalized and analyzed for the entire PCR reactions applied in 80 individual 96-well plate runs. As anticipated, extremely high levels of consistent performance was obtained for the universal control genes as a calibration standard (Table 2). A standard curve was constructed for all individual plate reactions applying the universal control genes $M S G, C A B, R B S 1$, and $A C T B$ (Additional File 1). A highly fitted master equation was established (Figure 4) using the pooled data for all reference control reactions as follows:

$$
\mathrm{Y}=25.941-3.4593 \mathrm{X}\left(\mathrm{R}^{2}=0.9999\right)
$$

where $\mathrm{X}$ represents mRNA $(\log \mathrm{pg}$ ) and Y equals qRTPCR cycle number $(\mathrm{Ct})$ estimated for all reactions performed on an ABI 7500 real time PCR System. Average PCR amplification efficiency for the entire reaction set was $95 \%$ (data not shown) as measured by the slope of the standard curves $[40,46]$.

\section{Enriched background of gene transcription abundance}

For ethanol-tolerant strain Y-50316, initial mRNA abundance of many genes showed significant difference without ethanol challenges compared with its parental strain Y-50049 under the same growth conditions. At the designated $0 \mathrm{~h}$, a time point the culture was incubated for $6 \mathrm{~h}$ before the ethanol addition, at least 35 genes were found having higher gene transcription abundance for the ethanol-tolerant yeast than its parental strain (Figure 5 and Table 3). In this group, 26 were first identified as ethanol tolerance related genes as follows: ELO1, GUP2, HSP31, PGM1, PFK1, PDA1, LPD1, IRC15, ADH2, ADH3, ADH7, ZWF1, SOL3, GND1, PRS1, PDR1, PDR5, PDR12, YOR1, SNQ2, ICT1, DDI1, TPO1, GRE2, YDR248C, and $Y M R 102 C$ (Table 3). Since the higher levels of transcripts were acquired through the tolerant adaptation procedures, these genes are considered as ethanol-tolerance related. They belong to groups of heat shock proteins, glycolysis, pentose phosphate pathway, fatty acid metabolism and the PDR gene family. The increased abundance for many genes was significantly higher in Y-50316 as compared with its parental strain Y-50049, especially for those in PDR gene family such as PDR5, YOR1, SNQ2, and GRE2.

\section{Transcription dynamics of heat shock protein genes}

All 14 examined heat shock protein genes demonstrated normal or enhanced expressions at the earlier stage, such as at 1 or $6 \mathrm{~h}$ after ethanol challenge for both strains (Figure 5 and 6). However, most heat shock protein genes in Y-50049 were repressed at 24 and $48 \mathrm{~h}$ and only three genes, HSP26, HSP3O and HSP31, remained induced for the parental strain Y-50049. But the expression abun- 
Table 2: Robust performance of standard control genes using $C A B$ as sole reference to set a manual threshold at $26 \mathrm{Ct}$ and a master equation derived from 80 replicated plate reactions on Applied Biosystems 7500 real time PCR System

\begin{tabular}{ccccccc}
\hline Control gene & Reference Ct & Mean Ct & Stdev & Estimated mRNA (pg) & Input mRNA (pg) & Consistency (\%) \\
\hline MSG & & 29.429 & 0.077 & 0.098 & 0.1 & 98.1 \\
CAB & 26.0 & 25.965 & 0.037 & 0.984 & 1 & 98.4 \\
RBS1 & & 22.388 & 0.019 & 10.64 & 10 & 93.6 \\
ACTB & & 15.604 & 0.019 & 973.25 & 1000 & 97.3 \\
\hline
\end{tabular}

dance of these genes was significantly less than that of the ethanol-tolerant strain Y-50316 (Table 3). Y-50316, on the other hand, had 10 genes, HSP12, HSP26, HSP30, HSP31, HSP32, HSP42, HSP78, HSP82, HSP104, and HSP150 showing significantly induced expressions from 24 to 48 h. Among these, HSP26 displayed the highest expression levels at all time points. Except for HSP4O and HSP90, all other heat shock protein genes of Y-50316 had distinct increased expression dynamics over time compared with its parental strain Y-50049 (Additional File 2). For example, HSP31 and HSP82 in Y-50316 were highly expressed at each time point. These heat shock proteins were found to be involved in cellular structure-function relationships at multiple locations including nucleus, mitochondrion, cytoplasm, cytoskeleton, membrane, and cell wall (Additional File 3).

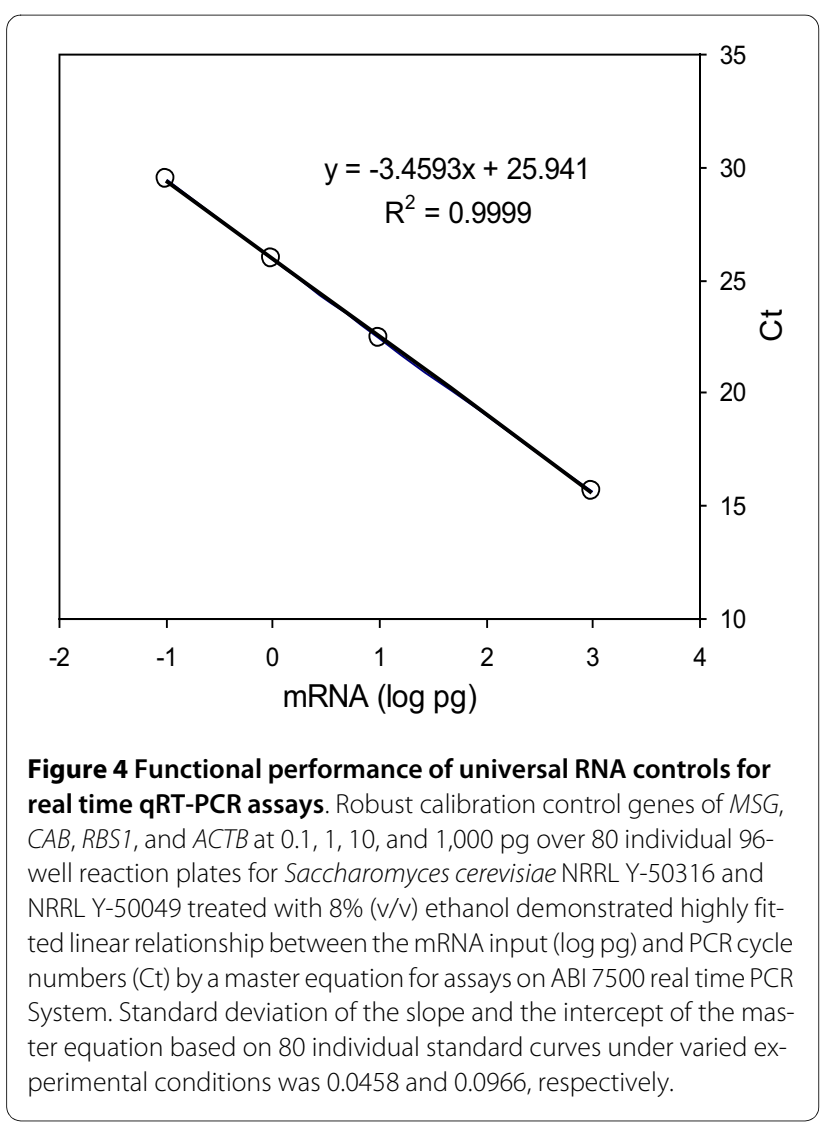

Adaptive expressions of trehalose and glucose metabolism genes

Although the initial transcription abundance was low, all examined trehalose and glycogen metabolism genes responded positively to the ethanol challenge over time. Transcription levels of the 11 trehalose metabolism genes in Y-50316 were consistently enhanced from 1 to $48 \mathrm{~h}$, especially for NTH1, NTH2, ATH1, TSL1, TPS1, GPH1, and GSY2 (Figure 5, Table 3 and Additional File 2). GPH1, a gene involved in glycogen catabolism had almost 20fold increased transcription abundance, the highest level in this group at $24 \mathrm{~h}$ for the tolerant Y-50316. Its expression levels were significantly greater at every time point compared with those of the parental strain (Table 3). GSY2 encoding for UDP-glucose-starch glucosyltransferase, another highly induced expressed gene in Y-50316, was identified as a new candidate gene for ethanol tolerance. For the parental strain Y-50049, most genes in this group had similar induced response at 1 and $6 \mathrm{~h}$ after the ethanol challenge. However, except for GPH1, all other 10 genes were reversed as repressed after $6 \mathrm{~h}$.

Transcription dynamic response was more complex for genes involving in glycolysis and pentose phosphate pathways. Many genes in this group demonstrated persistent high abundant expressions from 1 to $48 \mathrm{~h}$ after the ethanol challenge such as PGM2, HXK1, GLK1, TDH1, GPM2, IRC15, ALD4, ADH1, ADH2, ADH3, ADH7, SFA1, SOL4, GND2, NQM1, and YDR248C (Figure 5 and Table 3). Especially for GND2, $T D H 1$ and $N Q M 1$, their expression levels were constantly higher at all time points. The expression patterns of most genes in this group in Y50316 were distinct from that of its parental strain Y50049 , particularly after $6 \mathrm{~h}$ when many genes of the latter were significantly repressed. In addition to genes with enriched transcriptional abundance, at least another seven previously unreported genes in this group were identified as new candidate genes for ethanol-tolerance and ethanol production under the stress including $A D H 7$, SFA1, GND2, NQM1, SOL4, IRC15, and YDR248C (Table 3).

Many important genes in this group displayed a normal or non induced expressions under the ethanol challenge for the tolerant Y-50316 such as PGI1, PFK1, FBA1, 


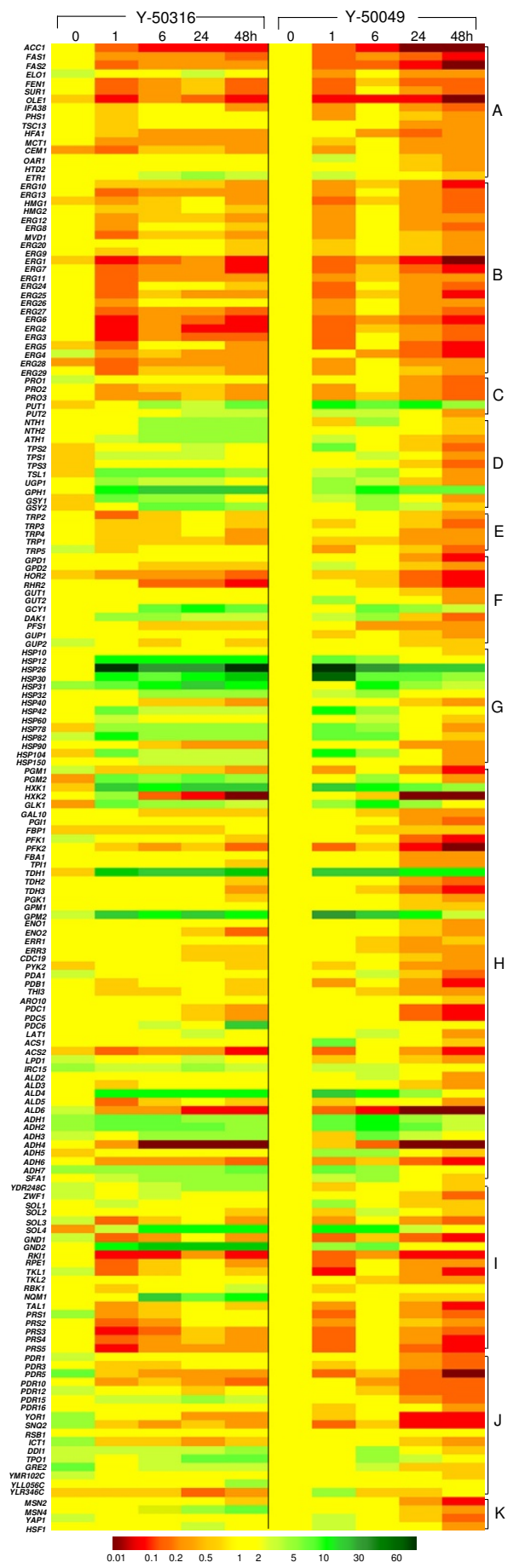

Figure 5 Gene expression under the ethanol stress. Comparison of mRNA expression of Saccharomyces cerevisiae NRRL Y-50316 and NRRL Y-50049 by fold changes from $0 \mathrm{~h}$ to $48 \mathrm{~h}$ after the ethanol challenge treatment. Corresponding genes were categorized by functions involved in fatty acid biosynthesis (A), ergosterol metabolism (B), proline metabolism (C), trehalose metabolism (D), tryptophan metabolism (E), glycerol metabolism (F), heat shock protein family $(\mathrm{G})$, glycolysis $(\mathrm{H})$, pentose phosphate pathway $(\mathrm{I})$, pleiotropic drug resistance gene family $(\mathrm{J})$ and related transcription factor genes $(K)$. Expressions for each gene at each time point were presented in relative fold changes against that of Y-50049 at $0 \mathrm{~h}$. Green indicates enhanced expression, red for repressed expression, and yellow for no significant changes. Scales of expressions were indicated by a an integrated color bar at the bottom. 
Table 3: Functional categories and comparative expression fold changes of candidate and key genes for ethanol tolerance and ethanol fermentation for tolerant Saccharomyces cerevisiae NRRL Y-50316 and its parental strain Y-50049 over time under the ethanol challenge

\begin{tabular}{|c|c|c|c|c|c|c|c|c|c|c|c|c|c|c|c|}
\hline \multirow{2}{*}{$\begin{array}{l}\text { Gene and } \\
\text { Category }\end{array}$} & \multirow{2}{*}{$\begin{array}{l}\text { Function } \\
\text { description }\end{array}$} & \multicolumn{8}{|c|}{$\mathrm{Y}-50316$} & \multicolumn{2}{|c|}{ Y-50049 } & \multirow{2}{*}{$\begin{array}{r}\text { Msn4p/ } \\
\text { Msn2p }\end{array}$} & \multirow[t]{2}{*}{ Yap1p } & \multirow[t]{2}{*}{ Hsf1p } & \multirow{2}{*}{$\begin{array}{r}\text { Pdr1p/ } \\
\text { Pdr3p }\end{array}$} \\
\hline & & $\mathbf{O h}$ & $1 \mathrm{~h}$ & $6 \mathrm{~h}$ & $24 \mathrm{~h}$ & $48 h$ & $\mathbf{O h}$ & $1 \mathrm{~h}$ & $6 \mathrm{~h}$ & $24 \mathrm{~h}$ & $48 h$ & & & & \\
\hline \multicolumn{16}{|c|}{ Heat shock proteins } \\
\hline HSP12 & $\begin{array}{l}\text { Plasma membrane } \\
\text { localized heat shock } \\
\text { protein }\end{array}$ & 0.7 & 5.2 & 7.8 & 6.7 & 5.6 & 1.0 & 4.3 & 2.1 & 1.3 & 1.2 & 7 & 0 & 1 & 0 \\
\hline HSP26 & $\begin{array}{l}\text { Small heat shock } \\
\text { protein with } \\
\text { chaperone activity }\end{array}$ & 0.9 & 55.2 & 30.0 & 31.7 & 54.4 & 1.0 & 59.5 & 34.8 & 17.8 & 15.3 & 4 & 0 & 7 & 0 \\
\hline HSP3O & $\begin{array}{l}\text { Hydrophobic } \\
\text { plasma membrane } \\
\text { localized heat shock } \\
\text { protein }\end{array}$ & 1.0 & 7.6 & 3.3 & 7.1 & 23.9 & 1.0 & 48.8 & 4.6 & 3.2 & 3.0 & 0 & 3 & 0 & 0 \\
\hline$H S P 31^{*}$ & $\begin{array}{l}\text { Member of the DJ-1/ } \\
\text { ThiJ/Pfpl } \\
\text { superfamily, } \\
\text { chaperone and } \\
\text { cysteine protease }\end{array}$ & 2.1 & 3.6 & 7.9 & 10.2 & 9.3 & 1.0 & 1.3 & 5.5 & 2.1 & 1.8 & 1 & 2 & 4 & 0 \\
\hline HSP32 & $\begin{array}{l}\text { Possible chaperone } \\
\text { and cysteine } \\
\text { protease }\end{array}$ & 0.8 & 1.0 & 2.4 & 2.1 & 2.3 & 1.0 & 1.5 & 2.1 & 1.4 & 1.0 & 4 & 0 & 6 & 0 \\
\hline HSP42 & $\begin{array}{l}\text { Small heat shock } \\
\text { protein with } \\
\text { chaperone activity }\end{array}$ & 0.8 & 3.8 & 1.5 & 1.6 & 1.6 & 1.0 & 6.9 & 2.8 & 1.2 & 0.7 & 3 & 0 & 8 & 0 \\
\hline HSP78 & $\begin{array}{l}\text { Heat shock protein } \\
\text { of ATP-dependent } \\
\text { proteases, } \\
\text { mitochondrial }\end{array}$ & 0.6 & 3.0 & 2.2 & 2.8 & 2.9 & 1.0 & 4.3 & 2.0 & 0.9 & 0.3 & 3 & 1 & 8 & 0 \\
\hline HSP82* & $\begin{array}{l}\text { Heat shock } \\
\text { protein,Hsp90 } \\
\text { chaperone required } \\
\text { for pheromone } \\
\text { signaling }\end{array}$ & 1.7 & 7.6 & 2.6 & 2.2 & 2.4 & 1.0 & 3.4 & 3.4 & 1.3 & 0.6 & 2 & 1 & 4 & 0 \\
\hline HSP104 & Heat shock protein & 0.5 & 3.7 & 1.6 & 1.7 & 1.9 & 1.0 & 8.8 & 2.6 & 1.0 & 0.4 & 3 & 1 & 10 & 0 \\
\hline HSP150 & $\begin{array}{l}\text { O-mannosylated } \\
\text { heat shock protein }\end{array}$ & 1.4 & 1.0 & 1.9 & 1.7 & 1.7 & 1.0 & 1.0 & 1.0 & 0.7 & 0.4 & 2 & 1 & 0 & 0 \\
\hline \multicolumn{16}{|c|}{ Trehalose and glycogen metablism } \\
\hline PGM1* & $\begin{array}{l}\text { Phosphoglucomuta } \\
\text { se, minor isoform }\end{array}$ & 1.6 & 0.6 & 0.6 & 0.6 & 0.4 & 1.0 & 0.4 & 0.7 & 0.3 & 0.2 & 3 & 0 & 2 & 0 \\
\hline PGM2 & $\begin{array}{l}\text { Phosphoglucomuta } \\
\text { se, major isoform }\end{array}$ & 0.4 & 3.6 & 2.6 & 3.8 & 2.3 & 1.0 & 1.4 & 2.4 & 0.9 & 0.5 & 7 & 1 & 0 & 0 \\
\hline UGP1 & $\begin{array}{l}\text { UDP-glucose } \\
\text { pyrophosphorylase }\end{array}$ & 1.1 & 2.4 & 1.5 & 1.9 & 1.2 & 1.0 & 2.6 & 1.5 & 0.6 & 0.3 & 5 & 0 & 2 & 0 \\
\hline GPH1 & $\begin{array}{l}\text { Glycogen } \\
\text { phosphorylase }\end{array}$ & 1.0 & 5.2 & 14.3 & 19.9 & 17.7 & 1.0 & 2.4 & 6.6 & 4.5 & 3.5 & 3 & 1 & 0 & 0 \\
\hline GSY1 & Glycogen synthase & 0.6 & 3.4 & 2.2 & 2.0 & 1.0 & 1.0 & 1.6 & 2.5 & 1.1 & 0.5 & 2 & 0 & 0 & 0 \\
\hline GSY2 & $\begin{array}{l}\text { UDP-glucose-- } \\
\text { starch } \\
\text { glucosyltransferase }\end{array}$ & 0.6 & 1.2 & 3.2 & 3.2 & 2.4 & 1.0 & 1.4 & 2.1 & 1.5 & 0.6 & 2 & 1 & 4 & 0 \\
\hline TSL1 & $\begin{array}{l}\text { alpha-trehalose- } \\
\text { phosphate synthase }\end{array}$ & 0.6 & 3.2 & 3.5 & 3.1 & 2.3 & 1.0 & 1.8 & 2.3 & 1.1 & 0.4 & 7 & 0 & 7 & 0 \\
\hline
\end{tabular}


Table 3: Functional categories and comparative expression fold changes of candidate and key genes for ethanol tolerance and ethanol fermentation for tolerant Saccharomyces cerevisiae NRRL Y-50316 and its parental strain Y-50049 over time under the ethanol challenge

\begin{tabular}{|c|c|c|c|c|c|c|c|c|c|c|c|c|c|c|c|}
\hline TPS1 & $\begin{array}{l}\text { alpha-trehalose- } \\
\text { phosphate synthase }\end{array}$ & 0.6 & 1.5 & 1.9 & 1.9 & 1.1 & 1.0 & 1.3 & 1.7 & 0.7 & 0.4 & 6 & 2 & 2 & 0 \\
\hline TPS3 & $\begin{array}{l}\text { Regulatory subunit } \\
\text { of trehalose-6- } \\
\text { phosphate } \\
\text { synthase/ } \\
\text { phosphatase } \\
\text { complex }\end{array}$ & 0.7 & 0.7 & 0.9 & 1.1 & 0.9 & 1.0 & 0.8 & 1.2 & 0.6 & 0.3 & 2 & 0 & 2 & 0 \\
\hline ATH1 & $\begin{array}{l}\text { Acid trehalase, } \\
\text { vacuolar }\end{array}$ & 1.1 & 1.6 & 2.1 & 2.2 & 2.0 & 1.0 & 1.7 & 1.2 & 0.6 & 0.4 & 1 & 1 & 4 & 0 \\
\hline NTH1 & Neutral trehalase & 0.9 & 1.3 & 2.3 & 2.7 & 2.5 & 1.0 & 0.6 & 2.0 & 1.2 & 0.5 & 3 & 0 & 2 & 0 \\
\hline NTH2 & alpha-trehalase & 1.0 & 1.4 & 2.1 & 2.8 & 2.8 & 1.0 & 0.9 & 1.4 & 0.9 & 0.5 & 1 & 1 & 2 & 0 \\
\hline \multicolumn{16}{|l|}{ Glycolysis } \\
\hline HXK1 & Hexokinase I & 0.5 & 16.8 & 6.9 & 13.1 & 15.8 & 1.0 & 14.1 & 8.1 & 3.8 & 2.2 & 5 & 0 & 4 & 0 \\
\hline GLK1 & Glucokinase & 0.4 & 4.0 & 2.7 & 2.4 & 1.8 & 1.0 & 2.5 & 6.3 & 2.3 & 0.8 & 4 & 0 & 0 & 0 \\
\hline$P G / 1$ & $\begin{array}{l}\text { Glycolytic enzyme } \\
\text { phosphoglucose } \\
\text { isomerase }\end{array}$ & 1.4 & 0.8 & 0.8 & 0.8 & 0.8 & 1.0 & 0.8 & 1.0 & 0.5 & 0.3 & 0 & 0 & 2 & 0 \\
\hline PFK1* & $\begin{array}{l}\text { Alpha subunit of } \\
\text { heterooctameric } \\
\text { phosphofructokinas } \\
\text { e involved in } \\
\text { glycolysis }\end{array}$ & 1.6 & 0.9 & 0.8 & 0.7 & 0.5 & 1.0 & 0.9 & 1.3 & 0.3 & 0.2 & 0 & 0 & 2 & 0 \\
\hline$F B A 1$ & $\begin{array}{l}\text { Fructose 1,6- } \\
\text { bisphosphate } \\
\text { aldolase }\end{array}$ & 1.2 & 1.0 & 0.8 & 0.9 & 0.7 & 1.0 & 0.9 & 1.0 & 0.4 & 0.3 & 0 & 1 & 1 & 0 \\
\hline $\mathrm{TDH} 1$ & $\begin{array}{l}\text { Glyceraldehyde-3- } \\
\text { phosphate } \\
\text { dehydrogenase } 1\end{array}$ & 0.6 & 25.8 & 16.4 & 17.8 & 20.2 & 1.0 & 11.4 & 17.3 & 9.8 & 5.9 & 2 & 2 & 0 & 0 \\
\hline $\mathrm{TDH} 2$ & $\begin{array}{l}\text { Glyceraldehyde-3- } \\
\text { phosphate } \\
\text { dehydrogenase } 2\end{array}$ & 1.3 & 1.3 & 1.0 & 0.7 & 0.5 & 1.0 & 1.1 & 1.1 & 0.4 & 0.2 & 0 & 0 & 0 & 0 \\
\hline$T D H 3$ & $\begin{array}{l}\text { Glyceraldehyde-3- } \\
\text { phosphate } \\
\text { dehydrogenase } 3\end{array}$ & 1.1 & 0.9 & 0.8 & 0.7 & 0.4 & 1.0 & 0.8 & 0.6 & 0.2 & 0.2 & 3 & 2 & 1 & 0 \\
\hline GPM2* & $\begin{array}{l}\text { Homolog of Gpm1p } \\
\text { phosphoglycerate } \\
\text { mutase }\end{array}$ & 1.6 & 10.4 & 6.1 & 10.2 & 5.6 & 1.0 & 34.6 & 16.9 & 5.2 & 1.8 & 1 & 3 & 4 & 0 \\
\hline ERR1 & $\begin{array}{l}\text { Enolase related } \\
\text { protein }\end{array}$ & 0.9 & 1.1 & 1.0 & 0.8 & 0.9 & 1.0 & 1.1 & 0.6 & 0.4 & 0.5 & 4 & 0 & 4 & 0 \\
\hline PYK2 & Pyruvate kinase & 0.7 & 0.9 & 0.9 & 0.9 & 0.5 & 1.0 & 0.5 & 1.1 & 0.5 & 0.3 & 1 & 1 & 0 & 0 \\
\hline IRC15* & $\begin{array}{l}\text { Putative } \\
\text { dihydrolipoamide } \\
\text { dehydrogenases }\end{array}$ & 2.1 & 1.9 & 1.6 & 2.2 & 1.8 & 1.0 & 2.0 & 1.6 & 1.2 & 0.8 & 2 & 1 & 2 & 0 \\
\hline LPD1* & $\begin{array}{l}\text { Dihydrolipoamide } \\
\text { dehydrogenase }\end{array}$ & 1.5 & 0.7 & 1.0 & 1.7 & 1.3 & 1.0 & 0.7 & 1.2 & 0.6 & 0.4 & 2 & 3 & 0 & 2 \\
\hline PDA ${ }^{*}$ & $\begin{array}{l}\text { E1 alpha subunit of } \\
\text { the pyruvate } \\
\text { dehydrogenase } \\
\text { (PDH) complex }\end{array}$ & 1.9 & 0.8 & 1.2 & 1.2 & 0.9 & 1.0 & 0.7 & 1.7 & 0.6 & 0.3 & 2 & 1 & 2 & 0 \\
\hline
\end{tabular}




\begin{tabular}{|c|c|c|c|c|c|c|c|c|c|c|c|c|c|c|c|}
\hline$A L D 4$ & $\begin{array}{l}\text { Mitochondrial } \\
\text { aldehyde } \\
\text { dehydrogenase, } \\
\text { utilizes NADP+or } \\
\text { NAD+ equally as } \\
\text { coenzymes }\end{array}$ & 0.9 & 5.3 & 7.8 & 7.0 & 6.1 & 1.0 & 11.3 & 5.3 & 2.8 & 1.4 & 3 & 3 & 0 & 0 \\
\hline$A L D 6^{*}$ & $\begin{array}{l}\text { Cytosolic aldehyde } \\
\text { dehydrogenase }\end{array}$ & 1.9 & 0.4 & 0.4 & 0.2 & 0.1 & 1.0 & 0.3 & 0.1 & 0.1 & 0.1 & 4 & 1 & 0 & 2 \\
\hline$A D H 1^{*}$ & $\begin{array}{l}\text { Alcohol } \\
\text { dehydrogenase I }\end{array}$ & 2.9 & 4.2 & 4.0 & 2.9 & 2.0 & 1.0 & 4.3 & 5.8 & 2.5 & 1.8 & 4 & 1 & 2 & 0 \\
\hline$A D H 2^{*}$ & $\begin{array}{l}\text { Alcohol } \\
\text { dehydrogenase II }\end{array}$ & 2.9 & 4.4 & 4.8 & 3.9 & 2.4 & 1.0 & 4.8 & 7.1 & 3.4 & 1.9 & 2 & 0 & 2 & 0 \\
\hline$A D H 3^{*}$ & $\begin{array}{l}\text { Alcohol } \\
\text { dehydrogenase III }\end{array}$ & 2.0 & 0.8 & 2.5 & 2.6 & 2.3 & 1.0 & 0.6 & 4.0 & 1.7 & 1.0 & 0 & 1 & 0 & 0 \\
\hline$A D H 7^{*}$ & $\begin{array}{l}\text { NADP(H)- } \\
\text { dependent alcohol } \\
\text { dehydrogenase }\end{array}$ & 2.9 & 2.6 & 2.3 & 2.4 & 3.2 & 1.0 & 3.9 & 2.9 & 1.4 & 1.1 & 1 & 2 & 2 & 0 \\
\hline SFA1 & $\begin{array}{l}\text { Long-chain alcohol } \\
\text { dehydrogenase }\end{array}$ & 1.2 & 1.7 & 2.0 & 2.4 & 2.3 & 1.0 & 1.9 & 2.3 & 1.0 & 0.6 & 1 & 0 & 2 & 0 \\
\hline \multicolumn{16}{|c|}{ Pentose phosphate pathway } \\
\hline$Z W F 1^{*}$ & $\begin{array}{l}\text { Glucose-6- } \\
\text { phosphate } \\
\text { dehydrogenase }\end{array}$ & 1.8 & 1.2 & 1.5 & 1.3 & 0.9 & 1.0 & 0.8 & 1.2 & 0.7 & 0.3 & 5 & 1 & 0 & 0 \\
\hline YDR248C* & $\begin{array}{l}\text { Sequence similarity } \\
\text { to bacterial and } \\
\text { human } \\
\text { gluconokinase }\end{array}$ & 1.7 & 0.7 & 1.5 & 3.0 & 2.4 & 1.0 & 0.7 & 1.4 & 0.7 & 0.5 & 3 & 1 & 0 & 0 \\
\hline SOL3* & $\begin{array}{l}\text { Possible 6- } \\
\text { phosphogluconolac } \\
\text { tonase }\end{array}$ & 1.8 & 0.3 & 0.6 & 1.3 & 0.4 & 1.0 & 0.4 & 0.9 & 0.4 & 0.3 & 1 & 3 & 0 & 0 \\
\hline SOL4 & $\begin{array}{l}\text { putative 6- } \\
\text { phosphogluconolac } \\
\text { tonase }\end{array}$ & 0.3 & 1.8 & 8.2 & 9.9 & 7.5 & 1.0 & 6.7 & 7.0 & 1.5 & 1.1 & 1 & 0 & 6 & 0 \\
\hline GND1* & $\begin{array}{l}\text { 6- } \\
\text { phosphogluconate } \\
\text { dehydrogenase }\end{array}$ & 1.8 & 0.3 & 0.3 & 0.9 & 0.5 & 1.0 & 0.3 & 0.6 & 0.3 & 0.1 & 1 & 0 & 0 & 0 \\
\hline GND2 & $\begin{array}{l}\text { 6- } \\
\text { phosphogluconate } \\
\text { dehydrogenase }\end{array}$ & 0.9 & 8.6 & 23.1 & 26.2 & 23.0 & 1.0 & 2.1 & 4.0 & 1.2 & 1.0 & 3 & 1 & 7 & 0 \\
\hline NQM1 & $\begin{array}{l}\text { Transaldolase of } \\
\text { unknown function }\end{array}$ & 1.1 & 0.8 & 10.2 & 3.4 & 6.1 & 1.0 & 1.2 & 1.1 & 0.6 & 0.6 & 3 & 1 & 2 & 0 \\
\hline$T K L 1^{*}$ & Transketolase 1 & 1.6 & 0.2 & 0.6 & 1.0 & 0.6 & 1.0 & 0.2 & 0.8 & 0.3 & 0.1 & 1 & 1 & 2 & 0 \\
\hline$T K L 2$ & Transketolase 2 & 0.9 & 0.8 & 1.3 & 0.7 & 1.1 & 1.0 & 1.0 & 0.5 & 0.5 & 0.5 & 2 & 2 & 1 & 0 \\
\hline PRS1* & $\begin{array}{l}\text { 5-phospho-ribosyl- } \\
\text { 1(alpha)- } \\
\text { pyrophosphate } \\
\text { synthetase }\end{array}$ & 2.2 & 0.3 & 0.5 & 1.0 & 0.9 & 1.0 & 0.3 & 1.1 & 0.4 & 0.3 & 0 & 2 & 6 & 0 \\
\hline
\end{tabular}

PDR family

PDR1* zinc finger

transcription factor

response 
Table 3: Functional categories and comparative expression fold changes of candidate and key genes for ethanol tolerance and ethanol fermentation for tolerant Saccharomyces cerevisiae NRRL Y-50316 and its parental strain Y-50049 over time under the ethanol challenge

\begin{tabular}{|c|c|c|c|c|c|c|c|c|c|c|c|c|c|c|c|}
\hline PDR5* & $\begin{array}{l}\text { Plasma membrane } \\
\text { ATP-binding } \\
\text { cassette (ABC) } \\
\text { transporter }\end{array}$ & 4.4 & 0.5 & 0.4 & 0.3 & 0.4 & 1.0 & 0.2 & 0.6 & 0.3 & 0.1 & 1 & 2 & 6 & 8 \\
\hline PDR12* & $\begin{array}{l}\text { Plasma membrane } \\
\text { ATP-binding } \\
\text { cassette (ABC) } \\
\text { transporter }\end{array}$ & 1.5 & 1.3 & 0.7 & 0.7 & 0.9 & 1.0 & 1.0 & 0.6 & 0.3 & 0.2 & 0 & 1 & 2 & 0 \\
\hline PDR15 & $\begin{array}{l}\text { ATP binding } \\
\text { cassette (ABC) } \\
\text { transporter of the } \\
\text { plasma membrane }\end{array}$ & 1.3 & 1.7 & 1.5 & 2.3 & 1.7 & 1.0 & 1.0 & 0.9 & 0.4 & 0.3 & 5 & 0 & 0 & 3 \\
\hline YOR1* & $\begin{array}{l}\text { ATP binding } \\
\text { cassette (ABC) } \\
\text { transporter of the } \\
\text { plasma membrane }\end{array}$ & 2.2 & 0.8 & 0.8 & 0.5 & 0.4 & 1.0 & 0.6 & 0.9 & 0.1 & 0.1 & 2 & 1 & 0 & 2 \\
\hline SNQ2* & $\begin{array}{l}\text { ATP binding } \\
\text { cassette (ABC) } \\
\text { transporter of the } \\
\text { plasma membrane }\end{array}$ & 2.3 & 0.6 & 0.4 & 0.7 & 0.5 & 1.0 & 0.3 & 0.5 & 0.2 & 0.1 & 1 & 2 & 0 & 7 \\
\hline$I C T 1^{*}$ & $\begin{array}{l}\text { Lysophosphatidic } \\
\text { acid acyltransferase }\end{array}$ & 2.0 & 0.6 & 0.6 & 0.4 & 0.6 & 1.0 & 1.0 & 1.2 & 0.7 & 0.4 & 1 & 0 & 2 & 2 \\
\hline DDI1* & $\begin{array}{l}\text { DNA damage- } \\
\text { inducible v-SNARE } \\
\text { binding protein }\end{array}$ & 1.7 & 1.7 & 2.0 & 1.7 & 2.4 & 1.0 & 1.1 & 2.0 & 1.0 & 0.6 & 1 & 1 & 0 & 0 \\
\hline TPO1* & $\begin{array}{l}\text { Vacuolar } \\
\text { polyamine-H+ } \\
\text { antiporter }\end{array}$ & 1.7 & 1.0 & 2.0 & 3.1 & 3.5 & 1.0 & 1.4 & 2.6 & 1.9 & 1.0 & 2 & 3 & 0 & 2 \\
\hline GRE2* & $\begin{array}{l}\text { Methylglyoxal } \\
\text { reductase (NADPH- } \\
\text { dependent) }\end{array}$ & 4.1 & 1.4 & 1.5 & 1.6 & 1.8 & 1.0 & 1.3 & 1.5 & 0.6 & 0.5 & 0 & 1 & 2 & 2 \\
\hline YMR102C* & $\begin{array}{l}\text { Protein of unknown } \\
\text { function }\end{array}$ & 1.6 & 1.2 & 1.1 & 1.2 & 1.0 & 1.0 & 1.2 & 0.9 & 0.7 & 0.6 & 1 & 0 & 0 & 3 \\
\hline
\end{tabular}

Fatty acid metabolism

ETR1 Mitochond respiratory function protein

ELO1* Elongase I, Fatty acid elongation protein

HTD2 Mitochondrial 3hydroxyacylthioester dehydratase involved in fatty acid biosynthesis

$\begin{array}{llllllllllllllllll}0.9 & 1.0 & \mathbf{1 . 5} & \mathbf{2 . 1} & \mathbf{1 . 7} & 1.0 & \mathbf{1 . 6} & 1.3 & 0.7 & 0.5 & 2 & 2 & 2 & 0 \\ \mathbf{1 . 6} & 0.8 & 1.3 & \mathbf{1 . 8} & 1.0 & 1.0 & 0.5 & 0.7 & 0.4 & 0.3 & 0 & 1 & 2 & 0 \\ 1.1 & 0.9 & 1.1 & 1.1 & 1.0 & 1.0 & 0.7 & 1.1 & 0.5 & 0.5 & 0 & 0 & 0 & 0 \\ & & & & & & & & & & & & & & & \end{array}$

Egosterol biosynthesis
ERG4* C-24(28) sterol reductase

ERG20 Farnesylpyrophosphate synthetase

$\begin{array}{llllllllllllll}1.5 & 0.5 & 0.6 & 0.5 & 0.3 & 1.0 & 0.7 & 0.4 & 0.2 & 0.2 & 0 & 0 & 2 & 2 \\ 0.9 & 0.7 & 0.9 & 0.9 & 0.6 & 1.0 & 0.6 & 1.3 & 0.6 & 0.4 & 1 & 1 & 0 & 0\end{array}$


Table 3: Functional categories and comparative expression fold changes of candidate and key genes for ethanol tolerance and ethanol fermentation for tolerant Saccharomyces cerevisiae NRRL Y-50316 and its parental strain Y-50049 over time under the ethanol challenge

\begin{tabular}{|c|c|c|c|c|c|c|c|c|c|c|c|c|c|c|c|}
\hline ERG26 & $\begin{array}{l}\text { C-3 sterol } \\
\text { dehydrogenase }\end{array}$ & 1.0 & 0.4 & 0.9 & 0.8 & 0.8 & 1.0 & 0.4 & 0.8 & 0.5 & 0.4 & 0 & 1 & 5 & 0 \\
\hline \multicolumn{16}{|c|}{ Proline metabolism } \\
\hline PUT1 & Proline oxidase & 0.6 & 0.8 & 2.7 & 1.8 & 4.9 & 1.0 & 5.1 & 3.8 & 6.0 & 2.6 & 0 & 0 & 0 & 0 \\
\hline$P R O 1^{*}$ & $\begin{array}{l}\text { Gamma-glutamyl } \\
\text { kinase, catalyzes the } \\
\text { first step in proline } \\
\text { biosynthesis }\end{array}$ & 1.6 & 1.0 & 0.7 & 0.9 & 0.7 & 1.0 & 0.7 & 1.0 & 0.5 & 0.3 & 0 & 0 & 2 & 0 \\
\hline
\end{tabular}

Tryptophan biosynthesis

TRP5* Tryptophan synthase

$\begin{array}{llllllllll}1.5 & 0.5 & 1.0 & 1.4 & 0.7 & 1.0 & 0.4 & 1.3 & 0.5 & 0.2\end{array}$

$4 \quad 2 \quad 0 \quad 0$

Glycerol metabolism

\begin{tabular}{|c|c|c|c|c|c|c|c|c|c|c|c|c|c|c|c|}
\hline$D A K 1$ & $\begin{array}{l}\text { Dihydroxyacetone } \\
\text { kinase }\end{array}$ & 1.2 & 2.2 & 2.0 & 1.9 & 1.8 & 1.0 & 1.6 & 2.0 & 0.7 & 0.3 & 0 & 0 & 0 & 0 \\
\hline GCY1 & $\begin{array}{l}\text { Putative NADP(+) } \\
\text { coupled glycerol } \\
\text { dehydrogenase }\end{array}$ & 1.1 & 0.9 & 4.3 & 5.4 & 4.8 & 1.0 & 1.1 & 4.1 & 2.2 & 1.7 & 1 & 1 & 2 & 0 \\
\hline GPD1 & $\begin{array}{l}\text { NAD-dependent } \\
\text { glycerol-3- } \\
\text { phosphate } \\
\text { dehydrogenase }\end{array}$ & 1.3 & 0.8 & 1.0 & 1.1 & 0.5 & 1.0 & 1.4 & 1.0 & 0.3 & 0.2 & 4 & 1 & 0 & 0 \\
\hline GUP1 & $\begin{array}{l}\text { Multimembrane- } \\
\text { spanning protein } \\
\text { essential for proton } \\
\text { symport of glycerol }\end{array}$ & 1.2 & 1.0 & 0.9 & 1.2 & 0.8 & 1.0 & 0.6 & 1.0 & 0.5 & 0.3 & 0 & 0 & 0 & 0 \\
\hline GUP2* & $\begin{array}{l}\text { Putative glycerol } \\
\text { transporter } \\
\text { involved in active } \\
\text { glycerol uptake }\end{array}$ & 1.8 & 0.8 & 0.6 & 1.0 & 0.6 & 1.0 & 0.7 & 1.0 & 0.6 & 0.5 & 1 & 0 & 0 & 0 \\
\hline
\end{tabular}

Transcription factors

\begin{tabular}{|c|c|c|c|c|c|c|c|c|c|c|c|c|c|c|}
\hline MSN2 & $\begin{array}{l}\text { Transcriptional } \\
\text { activator related to } \\
\text { Msn4p }\end{array}$ & 1.0 & 0.8 & 0.7 & 0.8 & 0.5 & 1.0 & 1.2 & 0.7 & 0.4 & 0.2 & 1 & 0 & 2 \\
\hline MSN4 & $\begin{array}{l}\text { Transcriptional } \\
\text { activator related to } \\
\text { Msn2p }\end{array}$ & 1.0 & 0.8 & 1.3 & 2.5 & 3.2 & 1.0 & 1.0 & 0.7 & 0.5 & 0.4 & 4 & 0 & 2 \\
\hline$Y A P 1^{*}$ & $\begin{array}{l}\text { Transcriptional } \\
\text { activator involved in } \\
\text { oxidative stress } \\
\text { response }\end{array}$ & 1.5 & 0.9 & 0.8 & 1.0 & 0.7 & 1.0 & 1.7 & 1.0 & 0.5 & 0.3 & 1 & 2 & 2 \\
\hline HSF1 & $\begin{array}{l}\text { Heat shock } \\
\text { transcription factor }\end{array}$ & 1.4 & 1.3 & 1.2 & 1.5 & 1.3 & 1.0 & 1.6 & 1.1 & 0.7 & 0.4 & 1 & 3 & 2 \\
\hline
\end{tabular}

* Genes showing significantly enriched transcription abundance in Y-50316 prior to ethanol challenge $(p<0.01)$.

Genes in bold indicate new reports by this study and the expression fold changes in bold indicate an increase of greater than 1.5 -fold ( $p<0.01)$ compared with a wild type control.

Numbers of protein binding motifs related to transcription factors Msn4p/Msn2p, Yap1p, Hsf1p and Pdr1p/Pdr3p for each gene were marked under each transcription factor 


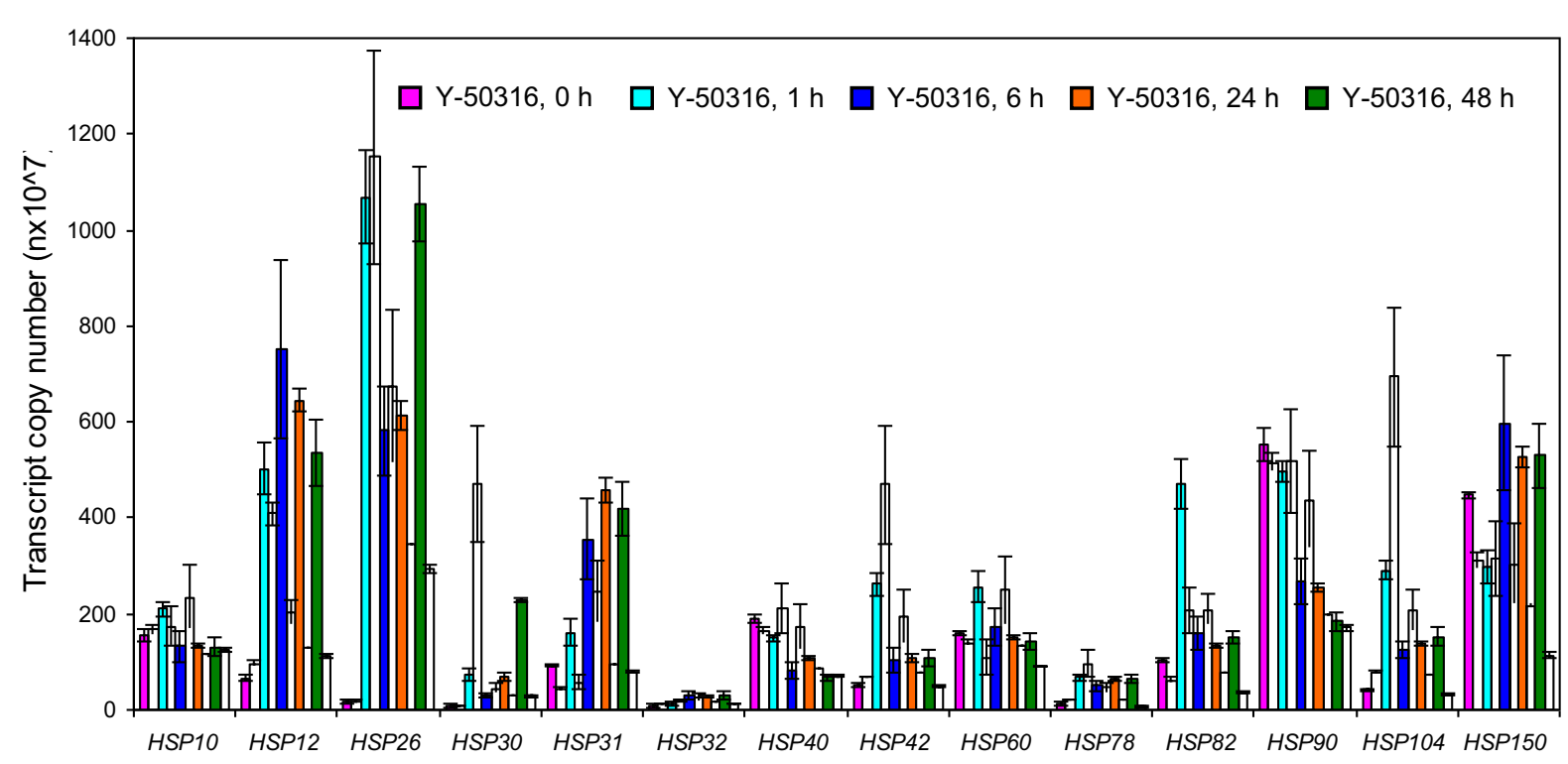

Figure 6 Quantitative expression of heat shock protein genes. Comparisons of transcription expressions in gene copy numbers ( $\mathrm{n} \times 10^{7}$ ) for heat shock protein genes between ethanol-tolerant strain Saccharomyces cerevisiae NRRL Y-50316 and its parental strain NRRL Y-50049 under the ethanol challenge over time. Mean values are presented with error bars of standard deviations. Values at different time points are presented by a specific colored bar as shown in legends for the tolerant Y-50316 and an immediately adjacent open bar on its right for its parental strain Y-50049 of the same time point.

TDH2, TDH3, TPI1, PGK1, GPM1, ENO1, EBO2, ERR1, ERR3, PYK2, CDC19, PDC1, PDC5, ARO10, THI3, ALD2, ALD3, ADH5, PDA1, PDB1, ACS1, SOL1, SOL2, TKL1, and TKL2 (Figure 7, Table 3 and Additional File 2). In contrast, for the parental Y-50049, most of these genes were repressed at the lower levels especially after $6 \mathrm{~h}$ (Figure 5). The transcript of ZWF1 in Y-50316 was not only enriched initially, but constantly displayed greater levels of expression at every time point compared with its parental Y-50049 (Table 3). Some enhanced genes in the tolerant Y-50316 are involved in multiple functions of carbohydrate metabolism and mitochondrion functions such as HXK1, GLK1, GND2, TDH1, SOL4, GPM2, $A D H 1$, and $A L D 4$ (Additional File 3).

\section{Enhanced expressions of PDR gene family}

Seventeen genes in this group were selected based on our preliminary tests of yeast stress tolerance. Among which, 13 genes were identified as candidate genes closely related to ethanol tolerance by enriched background of transcription abundance, increased, normal or recoverable expressions under ethanol challenge as demonstrated by the tolerant Y-50316 (Table 3 and Additional File 2). PDR15, DDI1, TPO1, and GRE2 maintained noticeable higher levels of expressions at all time points in addition to their enriched mRNA abundance at $0 \mathrm{~h}$ for Y-50316. Other genes in this group such as PDR1, PDR16, YMR102C, PDR3, PDR5, PDR12, PDR16, YOR1, and
SNQ2 for Y-50316 were expressed at normal levels or recoverable at later stages. On the other hand, these genes in Y-50049 were repressed.

\section{Comparative expressions of transcription factor genes}

In addition to the PDR 1 and $P D R 3$ expressions representing Pdr1p and Pdr3p described above, four other genes encoding transcription factors Msn4p, Msn2p, Yap1p and Hsf1p showed distinct expression patterns over time between the two strains. Expression levels of these four genes in Y-50049 were constantly reduced with the time exposed to ethanol (Figure 8). For the tolerant Y-50316, MSN2, YAP1 and HSF1 represented a similar type of expressions that was moderately repressed at 1 and $6 \mathrm{~h}$ after exposure to ethanol (Figure 8). At $24 \mathrm{~h}$, their expression levels were remarkably increased and significantly greater in Y-50316 than those in Y-50049. At 48, although significantly higher than the parental strain, transcription levels of these three genes in Y-50316 decreased. MSN4, on the other hand, displayed a unique type of continued increase of up-regulated expressions from 1 to $48 \mathrm{~h}$. At the critical time point of $6 \mathrm{~h}$, unlike the other three repressed genes, MSN4 expression in Y-50316 was consistently increased from the previous time point, significantly higher than the parental control (Figure 8 and Table 3). This consistent increase of transcription abundance was distinct and observed at $48 \mathrm{~h}$ again for MSN4 in Y-50316. 


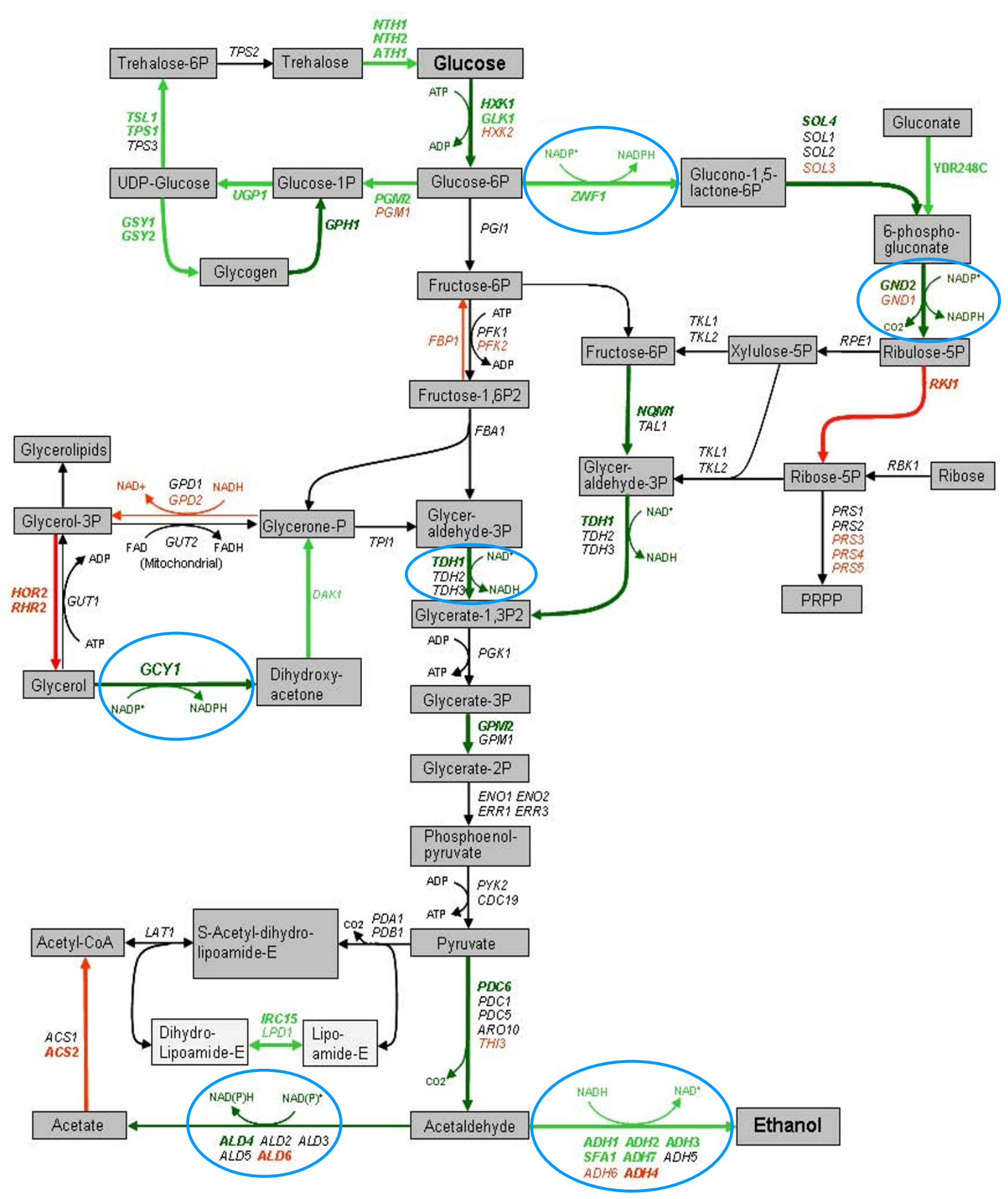

NTHO

Figure 7 Glucose metabolic pathway response. Illustrative pathways of ethanol- and inhibitor-tolerant mutant Saccharomyces cerevisiae NRRL Y50316 involved in trehalose-glycolysis-pentose phosphate pathway in response to ethanol challenges inferred by dynamic quantitative mRNA expression analysis and metabolic profiling analysis compared with its parental strain NRRL Y-50049. Dark green arrowed lines and letters indicate high levels (5.1-60 fold increase for at least one critical time point) of mRNA expression and enhanced pathways, green for significant levels (1.5-5 fold increase for at least one critical time point) of enhanced transcription and pathways; black indicates normal or nearly normal levels of transcription and pathway events, red for repressed expression, reactions, or pathways. Bold lines and letters indicate the levels of expression and pathways are statistically significant at $P<0.05$. Reactions involved in NAD(P)H regeneration steps are circled in blue. 


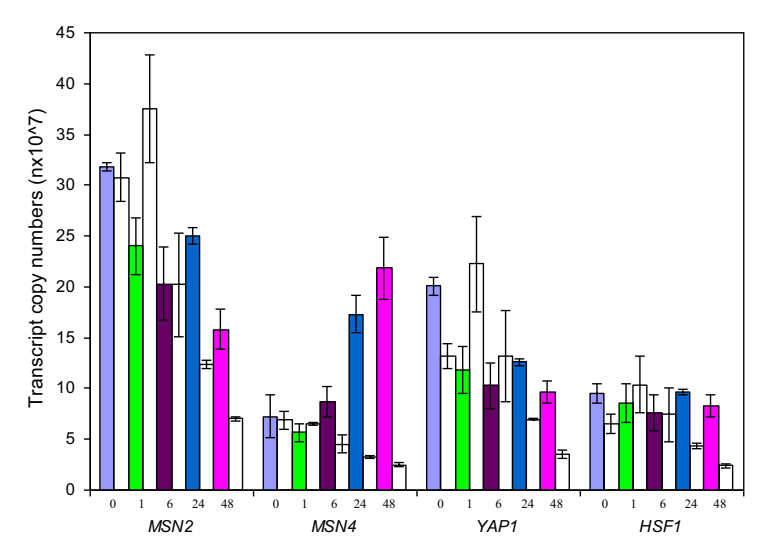

Figure 8 Expression response of transcription factor genes. Comparisons of transcription expressions in gene copy numbers ( $\left.\mathrm{n} \times 10^{7}\right)$ for transcription factor genes between ethanol-tolerant Saccharomyces cerevisiae NRRL Y-50316 and its parental strain NRRL Y-50049 under the ethanol challenge over time. Mean values are presented with error bars of standard deviations. Values at different time points are presented by a specific colored bar as shown in legends for the tolerant $Y$ 50316 and an immediately adjacent open bar on its right for the parental strain Y-50049 at the same time point.

\section{Transcriptional regulation under ethanol stress}

Most members of PDR gene family were found to have protein binding motifs of transcription factor Pdr1p/ Pdr3p in their promoter regions (Table 3). Significantly up-regulated PDR15, TPO1, GRE2 and YMR102C had at least two binding motifs. Several genes in other functional categories also shared the Pdr1p/Pdr3p binding site. The number of protein binding motifs of transcription factors Msn4p/Msn2p, Yap1p and Hsf1p for the ethanol tolerance candidate genes was remarkably large. Among 82 candidate genes of ethanol tolerance identified in this study, 77 genes were found to have a protein binding motif of Msn4p/Msn2p, Yap1p or Hsf1p; and 23 genes shared the common binding sequence for all of the three transcription factors (Figure 9 and Table 3). The four newly identified ethanol-tolerant candidate genes HSP31, HSP32, HSP150 and GND2 by this study were found to share the same transcription factor Msn4p/Msn2p. GND2, HSP31 and HSP32 also appeared co-regulated by Hsf1p, and GND2, HSP31 and HSP150, by Yap1p.

\section{Expression responses of other genes}

Expression levels of gene transcripts involved in fatty acid metabolism were generally low and repressed for both strains in response to the ethanol challenge except for ELO1, ETR1, PHS1, TSC13, OAR1, and HTD2 in Y-50316 having induced or recoverable expressions (Figure 5 and Table 3). Similarly, most genes in ergosterol metabolism group were repressed but ERG20, ERG24 and ERG26 in tolerant Y-50316 appeared to have normal or recoverable transcription expression potential over time (Figure 5 and

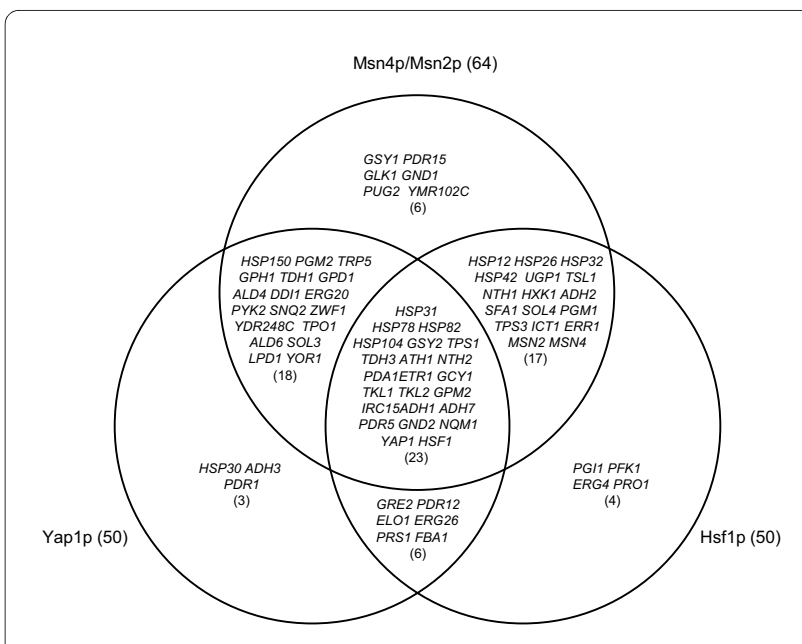

Figure 9 Shared protein binding motifs of candidate genes. A Venn diagram showing shared common protein binding motifs of transcription factors Msn4p/Msn2p, Hsf1p, and Yap $1 \mathrm{p}$ in their promoter regions for 82 candidate and key genes for ethanol tolerance and subsequent ethanol fermentation under ethanol stress in yeast.

Table 3). While all five tryptophan biosynthesis genes in parental Y-50049 were repressed over time, TRP5 in the tolerant Y-50316 was able to withhold the ethanol challenge (Table 3). Other four genes were mostly less repressed in Y-50316 than in Y-50049 (Additional File 2). Among five proline biosynthesis genes, PUT1 was induced for both strains. Expression patterns of most glycerol metabolism genes under ethanol challenge were similar for both strains with a few exceptions of Y-50316 genes including DAK1, GCY1, GPD1, GUP2, and GUP1.

\section{Discussion}

Applying a newly developed qRT-PCR array assays to unify gene expression data analysis, we demonstrated transcription expression dynamics for ethanol-tolerant mutant Y-50316 in response to ethanol challenge compared with its parental strain Y-50049 of S. cerevisiae. As opposed to a single "snapshot" observations, we used a more informative time-course design investigating selected gene expression response from initial $(0 \mathrm{~h})$, early growth $(1$ and $6 \mathrm{~h})$, exponential/log phase $(24 \mathrm{~h})$, and entering stationary phase $(48 \mathrm{~h})$ relative to the cell growth stage under the ethanol challenge. The dynamics of gene expression over time closely correlated with metabolic profiles and cell growth phenotypes between the two strains. This allowed identification of at least 82 candidate and key genes for ethanol tolerance and subsequent ethanol fermentation under the ethanol stress. Among which, 36 genes were the first report by the present study. Our results also suggest a potential key regulatory role of Msn4p for ethanol-tolerance among other transcription factor and regulatory elements. 
The newly developed data acquisition and analysis standard for qRT-PCR array assays using the robust mRNA as the PCR Ct reference provided reliable means to safeguard data fidelity and allowed unification of gene expression data for comparable analysis. Housekeeping genes are commonly used as quality controls for qRTPCR but vary under different experimental conditions $[42,47]$. Among numerous systems developed [41-45], the universal RNA controls have been shown another successful applications under ethanol stress conditions in this study. An extended adaptation and applications of such methods for consistent quantitative gene expression analyses are expected in the future.

Genes associated with ethanol stress were mostly reported based on snapshots of gene expression response in yeast $[11-13,15]$. In this study, we investigated a timecourse study comparing cell growth, viability, glucose-toethanol conversion, and gene expression dynamics for two closely related strains. This allowed assessment of phenotype associations and identification of legitimate candidate genes for ethanol tolerance. As demonstrated by this study, the parental strain showed briefly induced expression of numerous genes before becoming repressed and unable to establish a viable culture under the ethanol challenge. Uncovered by the expression dynamics of the tolerant strain, we are able to distinguish ethanol-tolerance candidate genes and tolerance-response from the transient stress-response in yeast. For example, unlike many heat shock protein genes in parental strain becoming repressed after $6 \mathrm{~h}$, these genes in the tolerant Y50316 showed continued inductions through $48 \mathrm{~h}$. This indicated that the continued expression of those heat shock protein genes after $6 \mathrm{~h}$ is critical for the ethanol tolerance in yeast.

Heat shock proteins, mainly act as chaperones, insuring properly folding or refolding of nascent or denatured proteins and enzymes to maintain functional conformation [48-50]. For example, Hsp12p, Hsp26p, Hsp42p, Hsp78p, and $\mathrm{Hsp} 82 \mathrm{p}$ were reported to prevent proteins from aggregating, and Hsp104p was able to disassemble protein aggregates that have accumulated in response to stress [51]. HSP82, a highly up-regulated gene in response to ethanol for the ethanol tolerant Y-50316 observed in our study, was reported to activate many key cellular regulatory and signaling proteins, such as transcription factors and regulatory kinases $[49,50,52,53]$. The lack of continued function of these genes and interactions with other relevant gene expression in Y-50049 led to no further metabolic functions. Recent proteomic studies suggested that mRNA is selectively processed and translated in stationary phase $[16,54]$. Our results of enhanced expressions of most heat shock protein genes at a relatively late stage such as 24 and $48 \mathrm{~h}$, for the tolerant Y50316 are supportive to this hypothesis.
In this study, we found three previously unreported heat shock protein genes, HSP31, HSP32 and HSP150, were highly enhanced in the tolerant Y-50316 and identified as candidate genes for the ethanol tolerance. Hsp31p and Hsp32p, functioning as a chaperone and cysteine protease, are involved in protein binding, peptidase and hydrolase activities. Significantly enhanced gene expressions of HSP31 and HSP32 in Y-50316 observed in this study suggests the potential involvement of Hsp31p and Hsp32p as chaperones against ethanol stress. In addition, HSP31 and HSP32 were found to have functions in cell component and biological process categories. Hsp150p is a protein involved in cell wall and structural molecule activity. Higher levels of transcription and continued expressions of HSP150 indicated its potential protective functions compared with its parental strain under the ethanol challenge. Many heat shock protein genes induced by ethanol stress are present in cytoplasm as well as in nucleus and mitochondrion [55]. Because up-regulated heat shock protein genes influence cell functions at multiple locations, this facilitates the functions of transcription factors in nucleus, improving ATP energy generation in metabolic processes, maintaining enzyme functions involving biosynthesis, catabolism, and ethanol production in cytoplasm.

The induced gene expressions related to trehalose and glycogen metabolism are expected to facilitate a stable intracellular environment under ethanol stress condition for survival and accelerated glucose metabolism. We found GSY2, a gene involved in glycogen biosynthesis and degradation was up-regulated over time as a new record. Since glycogen metabolism is very close to trehalose pathway, the two pathways likely affect each other. Storage carbohydrates such as trehalose are compatible solutes that can prevent cell dehydration and influx of excess salts into cells. Trehalose accumulation was observed under ethanol stress condition to reduce membrane permeability and proper folding of proteins $[17,24,56]$. Our findings of up-regulated TPS1, TSL1, PGM2, and UGP1 in this group were consistent with previously observed. Genes involved in trehalose degradation including NTH1, NTH2, and ATH1 were also induced by ethanol. These observations also agreed with previously reported $[11,12,17,29]$. Enhanced expression of trehalose degrading genes appeared to be necessary in order to balance trehalose concentration and energy required for cell functions $[11,57]$.

As demonstrated in this study, rapid cell growth and highly integrated expression of genes involved in trehalose biosynthesis, glycolysis and pentose phosphate pathway were closely correlated for the ethanol-tolerant strain Y-50316. Continued enhanced expressions of many genes associated in these groups apparently contributed active energy metabolism (Figure 7). In addition, numerous 
genes able to maintain normal expressions in Y-50316 appeared to be important keeping gene interactive networks. These genes are necessary for the tolerant yeast to carry out the active metabolisms and complete the ethanol fermentation (Figure 7) while most of these genes were repressed for the parental strain Y-50049. The ethanol-tolerant Y-50316 was co-selected for inhibitor-tolerance derived from its parental Y-50049. Under the ethanol challenge, the ethanol-tolerant Y-50316 displayed tolerant gene expression dynamics leading to similar route of pathway activities especially in every cofactor regeneration step. Cofactor NADPH plays an important role in biosynthesis of amino acids, lipids, and nucleotides [58,59]. Under the ethanol stress condition described in this study, the glucose metabolic pathways also appeared having a well-maintained cofactor redox balance (Figure 7) as exampled for GND2 and ZWF1 in oxidative phase of pentose phosphate pathway, $A L D 4$ in acetic acid production, and GCY1 in glycerol metabolism. Enhanced expression of ZWF1, SOL4, and YDR248C potentially provide sufficient substrate for a smooth pentose phosphate pathway flow. Therefore, sufficient NADPH supply likely contributes ethanol tolerance indirectly through efficient biosynthesis of amino acids, lipids, and nucleotides for cell growth and function. Similarly, TDH1 involved in NADH regeneration step was highly induced. The enhanced expressions of alcohol dehydrogenase genes $A D H 1, A D H 2, A D H 3, A D H 7$, and $S F A 1$, together with other normally expressed genes in the intermediate steps of glycolysis, are critical to complete the fermentation.

For the above mentioned reasons, we consider tryptophan and proline synthesis genes TRP5, PRO1, and PUT1 as ethanol tolerance candidate genes. Our results support the involvement of these genes in ethanol-tolerance as suggested by previous studies $[13,25,28]$. Several genes involving in fatty acid metabolism were repressed except for ETR1, ELO1 and HTD2 having induced and normal expressions for the tolerant Y-50316. Ergosterol is another major component of cellular membranes that associated with maintenance of plasma membrane fluidity affecting ethanol tolerance [14,28]. Similarly with previous reported $[11,12]$, most genes involved in ergosterol biosynthesis were repressed for both strains in this study. It is possible that the regulatory functions of the biosynthesis may not be significantly affected at transcriptional levels under the conditions of this study.

The PDR gene group is a new set of genes examined for ethanol tolerance in this study. Many PDR genes function as transporters of ATP-binding cassette proteins and are encoded for plasma membrane proteins that mediate membrane translocation of ions and a wide range of substrates. It impacts lipid and cell wall compositions and major facilitator superfamily proteins for cell detoxifica- tions [60]. We previously found that PDR genes and regulatory elements played significant roles for tolerance and in situ detoxification of lignocellulose-derived inhibitors [61]. Since plasma membrane and cell walls are major targets of ethanol damages, we anticipated the involvement of these genes for reconditioning and remodeling membrane and cell walls in response to ethanol challenges. The significantly enriched background of transcriptional abundance and continuously increased expressions of several genes in this group for the ethanol tolerant yeast observed in this study support our hypothesis (Table 3 ).

The expressions of PDR genes are mainly controlled by transcription factor Pdr1p and Pdr3p [62]. As demonstrated in our study, many genes share the common transcription protein binding motif of Pdr1p/Pdr3p. Expressions of PDR1 in the tolerant Y-50316 was not significantly induced but constantly expressed at all time points compared with the parental strain. It needs to be pointed out that unless it is repressed, PDR1 does not have to be greatly induced to allow potential Pdr1p functions as a regulator $[32,60]$. We consider the ability of its expression under the stress is a tolerance response and suggest Pdr1p as a potential regulator involving the ethanol tolerance of Y-50316. As discussed above, genes able to express or recover to express normally under the stress are important to maintain gene interactions and cell functions. On the other hand, transcription factor genes MSN4, MSN2, YAP1 and HSF1 of the tolerant strains were highly abundance under the ethanol stress. Since many ethanol tolerance candidate genes sharing protein binding motifs of Msn4p/Msn2p, Yap1p and Hsf1p, these transcription factors are likely a core set of regulators for interactive expressions of ethanol tolerance. An HSF1deletion mutant showed repressed expressions for its target genes usually induced by ethanol [63]. It has been demonstrated that Msn2p and Msn4p induces gene expression via a stress response element and triggers transcriptional response of the downstream genes $[64,65]$. Condition-specific roles in gene expression regulation by these transcription factors were also suggested [66]. Msn2p has been confirmed for its positive regulatory function of HSP12 and most heat shock protein genes for increased ethanol tolerance [67-69]. A double gene deletion msn2msn4-mutant showed hypersensitivity to environmental stress including higher ethanol concentrations [70]. We demonstrated that the increased expressions patterns of MSN4 overtime were distinct from other transcription factor genes. Our results suggest a potential key role of Msn4p in the dynamic response to the ethanol tolerance. However, limited information is available for Msn4p and further studies on its regulatory roles for tolerance are needed. 


\section{Conclusion}

The qRT-PCR array assay equipped with the robust mRNA reference and the master equation is an efficient means for quantitative gene expression analysis which unifies a large amount of expression data generated under different experimental conditions. The comparative characterizations of adaptive transcription dynamics for the two closely related strains are more informative and provide insight into dissection of mechanisms of ethanol tolerance. Analysis of the expression dynamics and association of other phenotypes allowed identification of candidate and key genes for the ethanol-tolerance and ethanol production under the stress. Enriched background of mRNA abundance of many genes appeared to be inheritable for the ethanol-tolerant yeast. Most ethanol-tolerance candidate genes were found sharing protein binding motifs of transcription factors Msn4p/Msn2p, Yap1p, Hsf1p and Pdr1p. The unique expression pattern of MSN4 in the ethanol-tolerant Y-50316 suggested a potential key regulatory role of Msn4p during the adaptive expression in yeast. Unlike repressed in the parental strain, genes able to maintain normal expressions under the ethanol-stress were necessary for the tolerant Y50316 to function. Ethanol-tolerance candidate genes identified in this study are primarily associated with functional categories of cytoplasm, membrane, cell wall, response to stress, transportot, protein folding, oxidoreductase activity, protein binding and unknowns classified by gene ontology (GO). However, multiple functions and functions at multiple loci of many candidate genes are common. Ethanol induced genes are involved in at least $79 \mathrm{GO}$ categories and every gene was found to have more than one function [55]. It's the time to revisit the traditional "one gene-one function" concept when evaluating gene regulatory networks. The complicated gene interactions cannot be overlooked in dissection of mechanisms of ethanol-tolerance in yeast.

\section{Methods}

\section{Yeast strains, medium, and culture conditions}

Ethanol-tolerant yeast S. cerevisiae NRRL Y-50316 and its inhibitor-tolerant parental strain NRRL Y-50049 (Agricultural Research Service Culture Collection, Peoria, IL, USA) were used in this study. Cultures were maintained and grown on a YM medium (3 g yeast extract, $3 \mathrm{~g}$ malt extract, and $5 \mathrm{~g}$ peptone, in $1 \mathrm{~L}$ distilled water) supplemented with 2 or $10 \%(\mathrm{w} / \mathrm{v})$ glucose. Cultures were incubated on $300 \mathrm{ml}$ medium in a fleaker system with agitation at $30^{\circ} \mathrm{C}$ as previously described [33]. A solid YM plate containing $2 \%$ agar was used to examine cell growth and viability. All experiments were carried out with two replications.

\section{Yeast adaptation and mutation selection}

Adaptation procedures were developed based on procedures by Wei et al. [36] and Dinh et al. [27] with modifications. Briefly, inhibitor-tolerant strain NRRL Y-50049 was cultured on a YM with $10 \%$ glucose containing ethanol in designated concentrations. Cultures were treated with a quick freeze at $-80^{\circ} \mathrm{C}$ at the mid-log phase and thawed at $30^{\circ} \mathrm{C}$ in a water-bath. The treatment procedures were repeated. Incubations were continued at $30^{\circ} \mathrm{C}$ until a stationary phase was reached. Surviving cultures were sequentially transferred to fresh medium containing higher ethanol concentrations. These procedures were repetitively carried out until a target tolerance level reached. Tolerant mutants were selected from at least 40 complete cycles using a medium containing no less than $8 \%$ ethanol. Culture characteristics were confirmed by cell morphology, growth rate, metabolic profiling, and sequence verification of its identity using nuclear large subunit ribosomal RNA gene [71].

\section{Assays for tolerance and viability}

Cells were grown at $30^{\circ} \mathrm{C}$ and $250 \mathrm{rpm}$ into the late exponential growth phase at $\mathrm{OD}_{600}$ reading of 1.0 when cultures contained approximately $1 \times 10^{7}$ cells $/ \mathrm{ml}$. An assay using serial dilutions of the culture was applied onto an YM plate of $2 \%$ glucose containing $8 \%(\mathrm{v} / \mathrm{v})$ ethanol for ethanol tolerance test using 10-fold serial dilutions of cell suspension. The culture plates were incubated at $30^{\circ} \mathrm{C}$ and examined 4 days after incubation. Tolerance to inhibitors furfural and HMF were examined in a similar manner on YM plates of $2 \%$ glucose containing $10 \mathrm{mM}$ each of furfural and HMF 7 days after incubation.

Cell viability was examined for cultures grown under a challenge with $8 \%$ of ethanol over time. The time point after 6-h pre-culture when ethanol was added into the culture was designated as $0 \mathrm{~h}$. Samples were taken starting at $24 \mathrm{~h}$ after the ethanol challenge until $168 \mathrm{~h}$ with a 24-h interval. Cell growth was examined on a solid YM using an assay similar as described above.

\section{Sample collection and HPLC analysis}

Cell growth was monitored by absorbance at $\mathrm{OD}_{600}$ under ethanol stress. Samples were taken and cells harvested at $0,1,6,24$, and $48 \mathrm{~h}$ after the $8 \%$ ethanol addition for mRNA expression analysis using procedures as previous described [41]. Yeast cells were immediately frozen on dry ice and then stored at $-80^{\circ} \mathrm{C}$ until use. Samples of culture supernatants were taken periodically from $0 \mathrm{~h}$ to 120 $\mathrm{h}$ after the ethanol challenge for metabolic profiling analysis. Glucose consumption, ethanol conversion, acetic acid, and glycerol production were measured using an HPLC system composed of a Waters 717 plus autosampler controlled at $10^{\circ} \mathrm{C}$, Waters 590 programmable pump, a Fast Acid column (Bio-Rad Laboratories, Hercules, CA) 
proceeded by a Microguard Cation $\mathrm{H}$ guard cartridge, a Spectra-Physics Spectra 100 variable wavelength UV detector $(215 \mathrm{~nm})$, and a Waters 2414 refractive index detector. The column was maintained at $65^{\circ} \mathrm{C}$, and samples were eluted with $1.6 \mathrm{mM} \mathrm{H}_{2} \mathrm{SO}_{4}$ at $0.6 \mathrm{ml} / \mathrm{min}$. A standard curve was constructed for each detected chemical and metabolic conversion product for HPLC assays as described previously $[33,38]$.

\section{Pathway-based qRT-PCR array assays}

Pathway-based qRT-PCR array assays were carried out using 96-well plates. Based on microarray studies, 175 genes involved in ethanol tolerance and ethanol production were selected for quantitative transcription analysis using qRT-PCR arrays. A recently developed robust data acquisition reference $C A B$ [40] and mRNA calibration standard [41] were applied for the qRT-PCR arrays. Primers of selected genes were designed (Additional File 4) using Primer 3 [72] with manual editing based on sequences of the Saccharomyces Genome Database [73]. Gene-specific amplification was verified by PCR and dissociation curve analysis. The length of designed amplicons of most tested genes ranged from 100 to $150 \mathrm{bp}$ with a few exceptions of shorter amplicons down to $75 \mathrm{bp}$ and one longer up to $210 \mathrm{bp}$.

Total RNA was isolated from each of two biological and two technical replications using procedures as previously described $[41,74]$. RNA integrity was verified by gel electrophoresis and NanoDrop Spectrophotometer ND-100 (NanoDrop Technologies, Inc., Wilmington, DE). Reverse transcription reactions applying the robust mRNA controls were carried out using procedures as previously described [40]. SYBR Green iTaq PCR master mix (BioRad Laboratories) was applied for each qRT-PCR reaction. For each reaction, a total of $25 \mu \mathrm{l}$ was used consisting of $12.5 \mu \mathrm{l} 2 \mathrm{X}$ SYBR Green MasterMix, $0.5 \mu \mathrm{l}$ each of forward and reverse primer (10 $\mu \mathrm{M}$ each), $0.25 \mu \mathrm{l}$ cDNA template, and $11.25 \mu \mathrm{l} \mathrm{H}_{2} \mathrm{O}$. On each 96-well plate, reactions of qRT-PCR were carried out with two replications for each control gene except for the control $C A B$ of three replications. All reactions of the tested target gene were run in duplicate. Control gene $B 2 M$ served as a non template negative control for each plate. PCR was run on an ABI 7500 real time PCR system using a defined profile as previously described [40]. A total of 8096 -well plates were applied for the qRT-PCR array assays. Transcription copy number of target genes was estimated using an equation based on the standard mRNA reference and master equation $[40,75]$ as follows:

Gene copy number $=\left[\operatorname{mRNA}(\mathrm{pg}) * 6.022 \times 10^{20}\right] /\left[\right.$ Amplicon $\left.(\mathrm{bp}) * 1 \times 10^{9} * 650\right]$ where mRNA is an estimated value in pg using the master equation and Amplicon is the amplified bp-length of an interested target gene.

\section{Data analysis}

Mean values of three $C A B$ amplifications on a plate were designated and used as a constant reference to set up a manual threshold at $26 \mathrm{Ct}$ (cycle number) for data analysis. This sole reference served as a constant standard for data acquisition and analysis for each and every qRT-PCR run. MasterqRT-PCR $\mathrm{C}^{++}$program http://cs1.bradley.edu/ nri/MasterqRT-PCR/[40] was used to generate a master equation, evaluate PCR amplification efficiency, and estimate transcript copy numbers as described previously $[37,40]$. Additional statistical analyses were performed using statistical function tools of Microsoft Excel. Quantitative expression data were correlated to metabolic profiling for ethanol tolerant strain Y-50316 and its parental strain Y-50049. Standard Gene Ontology (GO) annotations were carried out using GO Slim Mapper http://www.yeastgenome.org/cgi-bin/GO/goSlimMapper.pl. DNA binding motifs of transcription factors were annotated for candidate and key genes for ethanol tolerance and subsequent ethanol fermentation using YEASTRACT [76]. Previous knowledge of KEGG pathway database http://www.genome.jp/kegg/kegg.html was referenced for pathway constructions.

\section{Additional material}

Additional file 1 Performance of standard curves derived from robust
universal standard controls using CAB as the sole reference to set $\mathrm{Ct}$ at
26 by manual as threshold for data acquisition over 80 individual
plate reactions on Applied Biosystems 7500 real time PCR System
applying MasterqRT-PCR C $\mathrm{C}^{++}$program http://cs1.bradley.edu/ nri/
MasterqRT-PCR/
Additional file 2 Mean estimate of mRNA abundance in forms of tran-
script copy numbers ( $\times 10^{7}$ ) for selected genes of Saccharomyces
cerevisiae NRRL Y-50316 and NRRL Y-50049 in response to ethanol
challenge over a time-course study.
Additional file 3 Gene Ontology (GO) categories and terms of candi-
date and key genes for ethanol tolerance and fermentation under
stress in Saccharomyces cerevisiae.
Additional file 4 Primers used for mRNA expression analysis by real-
time qRT-PCR using SYBR Green.

Authors' contributions

ZLL designed the qRT-PCR array and conceived the experiment. MM performed strain adaptation, experimental fermentation, sample collection, RNA extraction, qRT-PCR and data analysis. ZLL and MM analyzed the data and wrote the manuscript. All authors read and approved the final manuscript.

\section{Acknowledgements}

We thank Scott Weber and Stephanie Thompson for technical assistance; to Michael Cotta for critically reading the manuscript. This work was supported in part by the National Research Initiative of the USDA Cooperative State

Research, Education, and Extension Service, grant number 2006-35504-17359. The mention of trade names or commercial products in this article is solely for the purpose of providing specific information and does not imply recommendation or endorsement by the U.S. Department of Agriculture. 


\section{Author Details}

'Bioenergy Research, National Center for Agricultural Utilization Research USDA-ARS, Peoria, IL USA and '2Department of Computer Science, New Mexico State University, Las Cruces, NM USA

Received: 24 February 2010 Accepted: 10 June 2010

Published: 10 June 2010

\section{References}

1. Bothast RJ, Saha BC: Ethanol production from agricultural biomass substrate. Adv App/ Microbiol 1997, 44:261-286.

2. Liu ZL, Saha BC, Slininger PJ: Lignocellulose biomass conversion to ethanol by Saccharomyces. In Bioenergy Edited by: Wall J, Harwood C, Demain A. ASM Press, Washington, DC; 2008:17-36.

3. Outlaw J, Collins K, Duffield J: Agriculture as a producer and consumer of energy. CAB International, Wallingford, UK; 2005

4. Sanchez OJ, Cardona CA: Trends in biotechnological production of fuel ethanol from different feedstocks. Bioresour Techno/ 2008, 99:5270-5295.

5. Wall JD, Harwood CS, Demain A: Bioenergy. ASM Press. Washington, DC, USA: 2008.

6. Zaldivar J, Nielsen J, Olsson L: Fuel ethanol production from lignocellulose: a challenge for metabolic engineering and process integration. App/ Microbiol Biotechnol 2001, 56:17-34.

7. Maiorella BL, Blanch HW, Wilke CR: Economic evaluation of alternative ethanol fermentation processes. Biotechnol Bioeng 1984, 16:1003-1025.

8. Bai FW, Chen LJ, Zhang Z, Anderson WA, Moo-Young M: Continuous ethanol production and evaluation of yeast cell lysis and viability loss under very high gravity medium conditions. J Biotechnol 2004, 110:287-293.

9. Gasch AP, Werner-Washburne M: The genomics of yeast responses to environmental stress and starvation. Funct Integr Genom 2002, 2:181-192.

10. Pina C, António J, Hogg T: Inferring ethanol tolerance of Saccharomyces and non-Saccharomyces yeasts by progressive inactivation. Biotechnol Lett 2004, 26:1521-1527.

11. Alexandre H, Ansanay-Galeote V, Dequin S, Blondin S: Global gene expression during short-term ethanol stress in Saccharomyces cerevisiae. FEBS Lett 2001, 498:98-103.

12. Chandler M, Stanley GA, Rogers P, Chambers P: A genomic approach to defining the ethanol stress response in the yeast Saccharomyces cerevisiae. Ann Microbiol 2004, 54:427-454

13. Hirasawa T, Yoshikawa K, Nakakura Y, Nagahisa K, Furusawa C, Katakura Y, Shimizu H, Shioya S: Identification of target genes conferring ethanol stress tolerance to Saccharomyces cerevisiae based on DNA microarray data analysis. J Biotechnol 2007, 131:34-44.

14. Yoshikawa K, Tanaka T, Furusawa C, Nagahisa K, Hirasawa T, Shimizu H: Comprehensive phenotypic analysis for identification of genes affecting growth under ethanol stress in Saccharomyces cerevisiae. FEMS Yeast Res 2009, 9:32-44.

15. Dinh TN, Nagahisa K, Yoshikawa K, Hirasawa T, Furusawa C, Shimizu H: Analysis of adaptation to high ethanol concentration in Saccharomyces cerevisiae using DNA microarray. Bioprocess Biosyst Eng 2009, 32:681-688.

16. Marks VD, Ho Sui SJ, Erasmus D, van der Merwe GK, Brumm J, Wasserman WW, Bryan J, van Vuuren HJJ: Dynamics of the yeast transcriptome during wine fermentation reveals a novel stress response. FEMS Yeast Res 2008, 8:35-52

17. Ogawa Y, Nitta A, Uchiyama H, Imamura T, Shiomoi H, Ito K: Tolerance mechanism of the ethanol-tolerant mutant of sake yeast. J BiosCi Bioeng 2000, 90:313-320.

18. Rossignol T, Dulau L, Julien A, Blondin B: Genome-wide monitoring of wine yeast gene expression during alcoholic fermentation. Yeast 2003, 20:1369-1385

19. Shobayashi M, Ukena E, Fujii T, lefuji H: Genome-wide expression profiles of sake brewing yeast under shocking and static conditions. Biosci Biotechnol Biochem 2007, 71:323-335.

20. Varela CJ, Cardenas J, Melo F, Agosin E: Quantitative analysis of wine yeast gene expression profiles under winemaking conditions. Yeast 2005, 22:369-383.

21. Wu H, Zheng X, Araki Y, Sahara H, Takagi H, Shimoi H: Global gene expression analysis of yeast cells during sake brewing. Appl Environ Microbiol 2006, 72:7353-7358.
22. Piper PW, Talreja K, Panareton B, Moradas-Ferreira P, Byrne K, Prnekelt UM, Meacock P, Reenacq M, Boucherie H: Induction of major heat-shock proteins of Saccharomyces cerevisiae, including plasma membrane HSP30, by ethanol levels above a critical-threshold. Microbiology 1994, 140:3031-3038.

23. Zuzuarregui A, Monteoliva L, Gil C, del Olmo M: Transcriptomic and proteomic approach for understanding the molecular basis of adaptation of Saccharomyces cerevisiae to wine fermentation. Appl Environ Microbiol 2006, 72:836-847.

24. Mansure JJC, Panek AD, Crowe LM, Crowe JH: Trehalose inhibits ethanol effects on intact yeast cells and liposomes. Biochim Biophys Acta 1994, 1191:309-316

25. Takagi H, Takaoka M, Kawaguchi A, Kubo Y: Effect of L-proline on sake brewing and ethanol stress in Saccharomyces cerevisiae. Appl Environ Microbiol 2005, 71:8656-8662.

26. Chi Z, Arneborg N: Relationship between lipid composition, frequency of ethanol-induced respiratory deficient mutants, and ethanol tolerance in Saccharomyces cerevisiae. J App/ Microbiol 1999, 86:1047-1052

27. Dinh TN, Nagahisa K, Hirasawa T, Furusawa C, Shimizu H: Adaptation of Saccharomyces cerevisiae cells to high ethanol concentration and changes in fatty acid composition of membrane and cell size. PLOSONE 2008, 3:e2623

28. Inoue T, lefuji H, Fujii T, Soga H, Satoh K: Cloning and characterization of a gene complementing the mutation of an ethanol-sensitive mutant of sake yeast. Biosci Biotechnol Biochem 2000, 64:229-236.

29. Kubota S, Takeo I, Kume K, Kanai M, Shitamukai A, Mizunuma M, Miyakawa $T$, Shimoi $H$, lefuji H, Hirata D: Effect of ethanol on cell growth of budding yeast: genes that are important for cell growth in the presence of ethanol. Biosci Biotechnol Biochem 2004, 68:968-972.

30. You KM, Rosenfield CL, Knipple DC: Ethanol tolerance in the yeast Saccharomyces cerevisiae is dependent on cellular oleic acid content. Appl Environ Microbiol 2003, 69:1499-1503.

31. Hu XH, Wang MH, Tan T, Li JR, Yang H, Leach L, Zhang RM, Luo ZW: Genetic dissection of ethanol tolerance in the budding yeast Saccharomyces cerevisiae. Genetics 2007, 175:1479-1487.

32. Liu ZL: Genetic dissection of ethanol tolerance in the budding yeast Saccharomyces cerevisiae. Appl Microbiol Biotechnol 2006, 73:27-36.

33. Liu ZL, Slininger PJ, Gorsich S: Enhanced biotransformation of furfural and 5-hydroxy methylfurfural by newly developed ethanologenic yeast strains. Appl Biochem Biotechnol 2005, 121-124:451-460.

34. Liu ZL, Slininger PJ, Dien BS, Berhow MA, Kurtzman CP, Gorsich SW: Adaptive response of yeasts to furfural and 5 - hydroxymethylfurfural and new chemical evidence for HMF conversion to 2,5-bishydroxymethylfuran. J Ind Microbiol Biotechnol 2004, 31:345-352.

35. Cakar ZP, Seker UO, Tamerler C, Sonderegger M, Sauer U: Evolutionary engineering of multiple-stress resistant Saccharomyces cerevisiae. FEMS Yeast Res 2005, 5:569-578.

36. Wei P, Li Z, Lin Y, He P, Jiang N: Improvement of the multiple-stress tolerance of an ethanologenic Saccharomyces cerevisiae strain by freeze-thaw treatment. Biotechnol Lett 2007, 29:1501-1508.

37. Liu ZL, Ma M, Song M: Evolutionarily engineered ethanologenic yeast detoxifies lignocellulosic biomass conversion inhibitors by reprogrammed pathways. Mol Genet Genomics 2009, 282:233-244.

38. Liu ZL, Moon J, Andersh BJ, Slininger PJ, Weber SA: Multiple gene mediated $\mathrm{NAD}(\mathrm{P}) \mathrm{H}$ dependent aldehyde reduction is a mechanism of in situ detoxification of furfural and 5-hydroxymethylfurfural by Saccharomyces cerevisiae. Appl Microbiol Biotechnol 2008, 81:743-753.

39. Applied Biosystems: Absolute quantification getting started guide for the 7300/7500 system. Applied Biosystems 2004

40. Liu ZL, Palmquist DE, Ma M, Liu J, Alexander NJ: Application of a master equation for quantitative mRNA analysis using qRT-PCR. J Biotechnol 2009, 143:10-16.

41. Liu ZL, Slininger PJ: Universal external RNA controls for microbial gene expression analysis using microarray and qRT-PCR. J Microbiol Methods 2007, 68:486-496.

42. Baker SC, Bauer SR, Beyer RP, Brenton JD, Bromley B, Burrill J, Causton H, Conley MP, Elespuru R, Fero M, Foy C, Fuscoe J, Gao X, Gerhold DL, Gilles P, Goodsaid F, Guo X, Hackett J, Hockett RD, Ikonomi P, Irizarry RA, Kawasaki ES, Kaysser-Kranich T, Kerr K, Kiser G, Koch WH, Lee KY, Liu C, Liu ZL, Lucas A, Manohar CF, Miyada G, Modrusan Z, Parkes H, Puri RK, Reid L, Ryder TB, Salit M, Samaha RR, Scherf U, Sendera TJ, Setterquist RA, Shi L, Shippy R, 
Soriano JV, Wagar EA, Warrington JA, Williams M, Wilmer F, Wilson M, Wolber PK, Wu X, Zadro R: The external RNA controls consortium: a progress report. Nat Methods 2005, 2:731-734

43. Ellefsen S, Stenslokken KO, Sandvik GK, Kristensen TA, Nilsson GE: Improved normalization of real-time reverse transcriptase polymerase chain reaction data using an external RNA control. Anal Biochem 2008, 376:83-93.

44. Kakuhata R, Wasahiro M, Yamamoto T, Akamine R, Yamazaki N, Kataoka M, Fukuoka S, Ishikawa M, Ooie T, Baba Y, Hori T, Shinohara Y: Possible utilization of in vitro synthesized mRNA specifically expressed in certain tissues as standards for quantitative evaluation of the results of microarray analysis. J Biochem Biophys Methods 2007, 70:755-760.

45. Reid LH, Lucas AB, Kopf-Sill AR, Chen B, Bromley B, Foy C, Hinkel CS, Boysen C, Liu CM, Ranamukha-arachchi D, Wagar E, Kawasaki ES, Goodsaid FM, Wilmer F, Fischer G, Kiser GL, Causton HC, Fuscoe JC, Brenton JD, Warrington JA, Soriano J, Coller J, Burrill JD, Rhodes K, Kerr KF, Zoon KC, Lee K, Shi LM, Salit M, Satterfield M, Marton M, Cronin M, Conley MP, Williams M, Fero M, Wilson M, Novoradovskaya N, Gilles P, Wolber PK, Ikonomi P, Puri R, Beyer RP, Shippy R, Setterquist R, Elespuru RK, Baker SC Chervitz SA, Bauer SR, Russell S, Kaysser Kranich T, Bammler TK, Ryder TB, Sendera TJ, Scherf U, Gao XL, Wu XN, Guo X, Liu ZL: Proposed methods for testing and selecting the ERCC external RNA controls. BMC Genomics 2005, 6:150

46. Applied Biosystem: Amplification efficiency of Taqman gene expression assays. 2006. Application Note Publication 127AP05-03

47. Barber RD, Harmer DW, Coleman RA, Clark BJ: GAPDH as a housekeeping gene: analysis of GAPDH mRNA expression in a panel of 72 human tissues. Physiol Genomics 2005, 21:389-395.

48. Gong Y, Kakihara Y, Krogan N, Greenblatt J, Emili A, Zhang Z, Houry WA: An atlas of chaperone-protein interactions in Saccharomyces cerevisiae: implications to protein folding pathways in the cell. Mol Syst Biol 2009, 5:275

49. McClellan AJ, Xia Y, Deutschbauer AM, Davis RW, Gerstein M, Frydman J: Diverse cellular functions of the $\mathrm{Hsp} 90$ molecular chaperone uncovered using systems approaches. Cell 2007, 131:121-135.

50. Young JC, Agashe VR, Siegers K, Hartl FU: Pathways of chaperone mediated protein folding in the cytosol. Nat Rev Mol Cell Biol 2004 5:781-791

51. Parsell DA, Kowal AS, Singer MA, Lindquist S: Protein disaggregation mediated by heat-shock protein Hsp104. Nature 1994, 372:475-478

52. Picard D: Heat-shock protein 90 , a chaperone for folding and regulation. Cell Mol Life Sci 2002, 59:1640-1648.

53. Prodromou C, Pearl LH: Structure and functional relationships of Hsp90. Curr Cancer Drug Targets 2003, 3:301-323.

54. Rossignol T, Kobi D, Jacquet-Gutfreund L, Blondin B: The proteome of a wine yeast strain during fermentation correlation with the transcriptome. J Appl Microbio/ 2009, 107:47-55.

55. Ma M, Liu ZL: Mechanisms of ethanol tolerance in Saccharomyces cerevisiae. Appl Microbiol Biotechnol 2010, 87:829-845.

56. Singer MA, Lindguist S: Multiple effects of trehalose on protein folding in vitro and in vivo. Mol Cell 1998, 1:639-648.

57. Sebollela A, Louzada PR, Sola-Penna M, Sarrone-Williams V, CoelhoSampaio T, Ferreira ST: Inhibition of yeast glutathione reductase by trehalose: possible implications in yeast survival and recovery from stress. Int J Biochem Cell Biol 2004, 36:900-908.

58. Bruinenberg PM, van Dijken JP, Scheffers WA: A theoretical analysis of NADPH production and consumption in yeasts. J Gen Microbio/ 1983, 129:953-964

59. Hou J, Lages NF, Oldiges M, Vemuri GN: Metabolic impact of redox cofactor perturbations in Saccharomyces cerevisiae. Metab Eng 2009. 11:253-261

60. Gulshan K, Moye-Rowley WS: Multidrug Resistance in Fungi. Eukaryot Cell 2007, 6:1933-1942.

61. Song M, Ouyang Z, Liu ZL: Discrete dynamic system modeling for gene regulatory networks of HMF tolerance for ethanologenic yeast. IET Sys Biology 2009, 3:203-218.

62. Mamnun YM, Pandjaitan R, Mahé Y, Delahodde A, Kuchler K: The yeast zinc finger regulators Pdr1 $p$ and Pdr3p control pleiotropic drug resistance (PDR) as homo- and heterodimers in vivo. Mol Microbio 2002, 46:1429-1440

63. Takemori Y, Sakaguchi A, Matsuda S, Mizukami Y, Sakurai H: Stressinduced transcription of the endoplasmic reticulum oxidoreductin gene ERO1 in the yeast Saccharomyces cerevisiae. Mol Genet Genomics 2006, 275:89-96.

64. Marchler G, Schuller C, Adam G, Ruis H: A Saccharomyces cerevisiae UAS element controlled by protein kinase $A$ activates transcription in response to a variety of stress conditions. EMBO J 1993, 12:1997-2003.

65. Schuller C, Brewster JL, Alexander MR, Gustin MC, Ruis H: The HOG pathway controls osmotic regulation of transcription via the stress response element (STRE) of the Saccharomyces cerevisiae CTT1 gene. EMBO J 1994, 13:4382-4389.

66. Berry DB, Gasch AP: Stress-activated genomic expression changes serve a preparative role for impending stress in yeast. Mol Biol Cell 2008, 19:4580-4587.

67. Watanabe M, Tamura K, Magbanua JP, Takano K, Kitamoto K, Kitagaki H, Akao T, Shimoi H: Elevated expression of genes under the control of stress response element (STRE) and Msn2p in an ethanol-tolerance sake yeast Kyokai no. 11. J Biosci Bioeng 2007, 104:163-170.

68. Watanabe M, Watanabe D, Akao T, Shimoi H: Overexpression of MSN2 in a sake yeast strain promotes ethanol tolerance and increases ethanol production in sake brewing. J Biosci Bioeng 2009, 107:516-518.

69. Wu WS, Li WH: Identifying gene regulatory modules of heat shock response in yeast. BMC Genomics 2008, 9:439.

70. Moskvina E, Schuller C, Maurer CT, Mager WH, Ruis H: A search in the genome of Saccharomyces cerevisiae for genes regulated via stress response elements. Yeast 1998, 14:1041-1050.

71. Kurtzman CP, Robnett CJ: Identification and phylogeny of ascomycetous yeasts from analysis of nuclear large subunit (26S) ribosomal DNA partial sequences. Antonie van Leeuwenhoek 1998, 73:331-371

72. Rozen S, Skaletsky H: Bioinformatics methods and protocols. In Methods in molecular biology Edited by: Krawetz S, Misener S. Humana Press, Totowa; 2000:365-386.

73. Fisk DG, Ball CA, Dolinski K, Engel SR, Hong EL, Issel-Tarver L, Schwartz K, Sethuraman A, Botstein D, Cherry JM: Saccharomyces cerevisiae S288C genome annotation: a working hypothesis. Yeast 2006, 23:857-865.

74. Hegde P, Qi R, Abernathy K, Gay C, Dharap S, Gaspard R, Earle-Hughes J, Snesrud E, Lee N, Quackenbush J: A concise guide to CDNA microarray analysis. BioTechniques 2000, 29:548-562.

75. Staroscik A: Calculator for determining the number of copies of a template. 2004 [http://www.uri.edu/research/gsc/resources/ cndna.html].

76. Teixeira MC, Monteiro P, Jain P, Tenreiro S, Fernandes AR, Mira NP, Alenquer M, Freitas AT, Oliveira AL, Sá-Correia I: The YEASTRACT database: a tool for the analysis of transcription regulatory associations in Saccharomyces cerevisiae. Nucl Acids Res 2006, 34:D446-451.

doi: $10.1186 / 1471-2180-10-169$

Cite this article as: $\mathrm{Ma}$ and Liu, Quantitative transcription dynamic analysis reveals candidate genes and key regulators for ethanol tolerance in Saccharomyces cerevisiae BMC Microbiology 2010, 10:169

\section{Submit your next manuscript to BioMed Centra and take full advantage of:}

- Convenient online submission

- Thorough peer review

- No space constraints or color figure charges

- Immediate publication on acceptance

- Inclusion in PubMed, CAS, Scopus and Google Scholar

- Research which is freely available for redistribution 